Portland State University

PDXScholar

6-13-1996

\title{
Correction of Classroom Oral Errors: Preferences among University Students of English in Japan
}

Akemi Katayama

Portland State University

Follow this and additional works at: https://pdxscholar.library.pdx.edu/open_access_etds

Part of the Bilingual, Multilingual, and Multicultural Education Commons Let us know how access to this document benefits you.

Recommended Citation

Katayama, Akemi, "Correction of Classroom Oral Errors: Preferences among University Students of English in Japan" (1996). Dissertations and Theses. Paper 5282.

https://doi.org/10.15760/etd.7155

This Thesis is brought to you for free and open access. It has been accepted for inclusion in Dissertations and Theses by an authorized administrator of PDXScholar. Please contact us if we can make this document more accessible: pdxscholar@pdx.edu. 
THESIS APPROVAL

The abstract and thesis of Akemi Katayama for the Master of Arts in

Teaching English to Speakers of Other Languages were presented June 13, 1996, and accepted by the thesis committee and the department.

COMMITTEE APPROVALS:

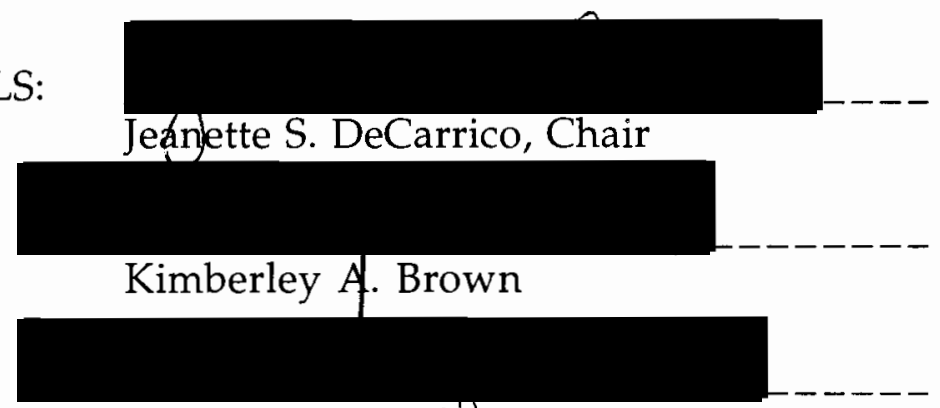

Patricia J. Wetzel V

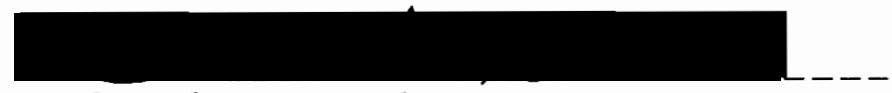

Suwako Watanabe

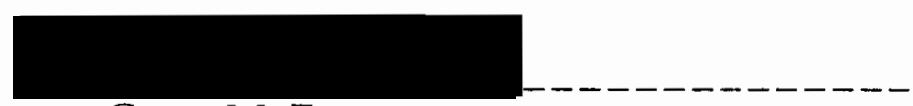

Grant M. Farr

Representative of the Office of Graduate Studies

DEPARTMENT APPROVAL:

Beatrice T. Oshika, Chair

Department of Applied Linguistics

ACCEPTED FOR PORTLAND STATE UNIVERSITY BY THE LIBRARY

by

on

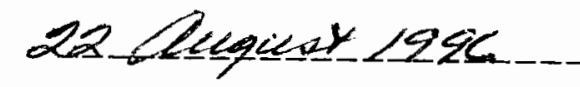




\begin{abstract}
An abstract of the thesis of Akemi Katayama for the Master of Arts in Teaching English to Speakers of Other Languages presented June 13, 1996.

Title: Correction of Classroom Oral Errors: Preferences among University Students of English in Japan
\end{abstract}

Correction of oral errors in foreign or second language classrooms has been an issue of great concern. Although the literature on error correction is abundant, the studies on student reaction to this pedagogical practice are few.

This study investigated the preferences for correction of classroom oral errors among university students of English in Japan. Data were collected from anonymous questionnaires. The study examined the students' attitudes toward the views about correction of oral errors which have been controversial among foreign and second language educators. The study also investigated the students' preferences for correction of different types of oral errors (e.g., grammatical errors) and particular types of correction as well.

The results showed that the students had a strong positive agreement regarding teacher correction of oral errors. They showed a tendency toward agreement concerning peer correction, and a slight tendency toward agreement regarding selective error correction. 
Concerning overcorrection of errors, they showed a tendency toward disagreement. There was no significant difference among the different levels of oral English proficiency.

The students had positive attitudes toward the correction of all five types of errors listed in the questionnaire: grammatical errors, phonological errors, and errors regarding vocabulary, pragmatics, and discourse. Pragmatic errors received the strongest preference. A significant difference among the proficiency levels was observed in only preference for correction of discourse errors.

Preferred methods of error correction were: 1) the teacher gives the student a hint which might enable the student to notice the error and selfcorrect, 2) the teacher explains why the response is incorrect, 3) the teacher points out the error, and provides the correct response, and 4) the teacher presents the correct response or part of the response. The methods disliked were: 1) the teacher ignores the student's errors and 2) the teacher repeats the original question asked of the student. A significant difference among the groups was observed in preference for only one error correction method: the teacher presents the correct response or part of the response. 
CORRECTION OF CLASSROOM ORAL ERRORS:

PREFERENCES AMONG UNIVERSITY

STUDENTS OF ENGLISH IN JAPAN

by

AKEMI KATAYAMA

A thesis submitted in partial fulfillment of the

requirements for the degree of

MASTER OF ARTS

in

TEACHING ENGLISH TO SPEAKERS OF OTHER LANGUAGES

Portland State University

1996 


\section{ACKNOWLEDGMENT}

I would like to take this opportunity to express my appreciation to the individuals who provided assistance to this study. Special thanks to Dr. Jeanette S. DeCarrico, my advisor and committee chair, for her encouragement and pertinent guidance. My appreciation is also extended to the other members of my committee, Dr. Kimberley A. Brown, Dr. Grant M. Farr, Dr. Suwako Watanabe, and Dr. Patricia J. Wetzel, who provided insightful comments and constructive suggestions to the study.

I would also like to acknowledge Dr. Erik Terdal for his immense contribution to statistical analysis; Dr. Jayne Sowers for her advice and proofreading; and Dr. Michael Lazarin and Dr. Carol Rinnert for their contribution to the subject recruitment in the study. I am also grateful for the support from the teachers, who allowed me to conduct the survey in their classes: Dr. Peter High, Dr. Hiroe Kobayashi, and many others. In addition, and most importantly, I owe the greatest thanks to the Japanese students who participated in this study.

Finally, I wish to extend my appreciation to my family and friends for their invariable support and constant encouragement. 


\section{TABLE OF CONTENTS}

\section{PAGE}

ACKNOWLEDGMENTS $\ldots \ldots \ldots \ldots \ldots \ldots \ldots \ldots \ldots$

LIST OF TABLES $\ldots \ldots \ldots \ldots \ldots \ldots \ldots \ldots \ldots \ldots \ldots \ldots \ldots \ldots \ldots \ldots \ldots$ viii

LIST OF FIGURES $\ldots \ldots \ldots \ldots \ldots \ldots \ldots \ldots \ldots \ldots \ldots \ldots \ldots \ldots \ldots \ldots \ldots$ CHAPTER

I INTRODUCTION $\ldots \ldots \ldots \ldots \ldots \ldots \ldots \ldots \ldots$

Statement of Problem $\ldots \ldots \ldots \ldots \ldots \ldots \ldots \ldots$

Purpose of the Study $\ldots \ldots \ldots \ldots \ldots \ldots \ldots, 2$

Research Questions .................. 3

II LITERATURE REVIEW $\ldots \ldots \ldots \ldots \ldots \ldots \ldots \ldots$

Introduction $\ldots \ldots \ldots \ldots \ldots \ldots \ldots \ldots \ldots$

Changing Perspectives on Learner Errors ..... 6

Research on Error Correction ............. 12

Research on Students' Attitudes Toward Error

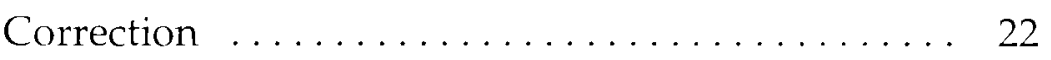

Summary $\ldots \ldots \ldots \ldots \ldots \ldots \ldots \ldots \ldots \ldots \ldots \ldots \ldots \ldots$

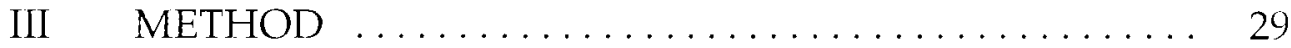

Introduction $\ldots \ldots \ldots \ldots \ldots \ldots \ldots \ldots \ldots \ldots$

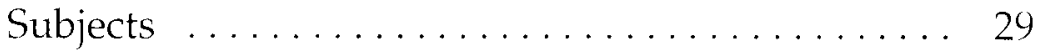

Instrument $\ldots \ldots \ldots \ldots \ldots \ldots \ldots \ldots \ldots \ldots$

Procedures $\ldots \ldots \ldots \ldots \ldots \ldots \ldots \ldots \ldots \ldots, 37$ 
Introduction $\ldots \ldots \ldots \ldots \ldots \ldots \ldots \ldots \ldots \ldots \ldots$

Demographic Data ................ 43

Preferences for Correction of Oral Errors . . . . . 45

Preferences for Error Correction on Different Aspects of the Language .............. 53

Preferences for Types of Error Correction . . . . . 59

Differences in Preference Between Subgroups . . 67

V DISCUSSION $\ldots \ldots \ldots \ldots \ldots \ldots \ldots \ldots \ldots \ldots \ldots$

Introduction $\ldots \ldots \ldots \ldots \ldots \ldots \ldots \ldots \ldots \ldots$

Discussion of Research Questions and

Hypotheses ................. 73

Discussion of Differences in Preference

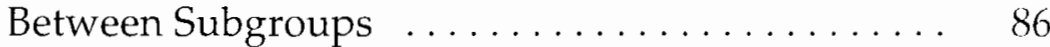

Limitations $\ldots \ldots \ldots \ldots \ldots \ldots \ldots \ldots \ldots$

Implications $\ldots \ldots \ldots \ldots \ldots \ldots \ldots$

Suggestions for Further Study $\ldots \ldots \ldots \ldots \ldots 1$

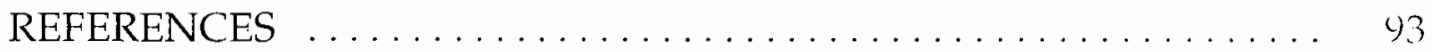

APPENDICES

A QUESTIONNAIRE IN ENGLISH $\ldots \ldots \ldots \ldots \ldots \ldots \ldots$

B QUESTIONNAIRE IN JAPANESE ... . . . . . . . 110 


\section{LIST OF TABLES}

TABLE

PAGE

I Demographic Date of Respondents. . . . . . . . . . . . 44

II Reasons of Responses to a Statement,"I Want Teachers to Correct My errors in Speaking English." ............ 46

III Reasons of Responses to a Statement, "Teachers Should Correct All Errors That Learners Make in Speaking English."

IV Reasons of Responses to a Statement, "Teachers Should Correct Only Those Errors That Interfere with Communication." ......................... 50

V Reasons of Responses to a Statement, "I Want My Classmates to Correct My Oral Errors in Group Work." . . . . . . . . . . 52

VI Preferred Methods of Errors Correction: Percentage of Response. .............................62 62

VII Methods Neither Preferred Nor Disliked: Percentage of Response. .............................. 64

VIII Unfavored Methods: Percentage of Response. . . . . . . . 65 


\section{LIST OF FIGURES}

FIGURE

PAGE

1 Responses to a Statement, "I Want Teachers to Correct My Errors in Speaking English." .................. 45

2 Responses to a Statement, "Teachers Should Correct All Errors That Learners Make in Speaking English." ... . . . 47

3 Responses to a Statement, " Teachers Should Correct Only Those Errors That They Interfere with Communication."

4 Responses to a Statement, " I Want My Classmates to Correct My Oral Errors in Group Work." . ................ 51

5 Preferences for Correction of Errors Regarding Pragmatics

6 Preferences for Correction of Phonological Errors. ...... 54

$7 \quad$ Preferences for Correction of Vocabulary Errors. . . . . . . . 56

8 Preferences for Correction of Grammatical Errors. . . . . . . 57

9 Preferences for Correction of Errors Regarding Discourse. 58 


\section{CHAPTER I}

\section{INTRODUCTION}

\section{STATEMENT OF PROBLEM}

Many language teachers using communicative approaches have encountered students who complain if their every oral error is not corrected, or if they are required to express something that they have not practiced. On the other hand, students who value communicative effectiveness over grammatical accuracy will likely have negative reactions when their utterances are constantly corrected (Horwitz, 1988).

The findings of some research (e.g., Cathcart and Olsen, 1976; Nunan, 1993; Oladejo, 1993) show important differences between the views and practices of linguists and teachers on the one hand, and learners' preferences and expectations on the other. Horwitz (1990) cautions that this mismatch in teachers' and students' expectations can contribute to unsatisfactory instructional outcomes.

Some other researchers support the view that matching of the learners' preferences and the teachers' practices is important for successful language learning (Cathcart and Olsen, 1976; McCargar, 1993; Oladejo, 1993). The importance of learners' preferences is discussed by Strevens (1977), who claims that the most important and the most effective reason 
for successful language learning and teaching is that teachers "cherish" their students, i.e., teachers "show concern" for their students, "find out" their interests, "discover their learning preferences," etc. (p.274).

In agreement with concern for learners' preference, Kern (1995) maintains that research on learners' perceptions can help "predict expectational conflicts that may contribute to student frustration, anxiety, lack of motivation, and, in some cases, ending of foreign language study" (p.71).

While the literature on teachers' response to students' errors is numerous, the literature on students' reaction to error correction is limited in both English as a foreign and second language research (Cathcart and Olsen, 1976; Chenoweth, Day, Chun, \& Leppescu, 1983; Oladejo, 1993). Specifically concerning Japanese learners' preferences for oral error correction, there is very little research in the literature. The only study that the researcher identified for purposes here is Chenoweth et al.'s (1983). Chenoweth et al. examined the attitudes toward error correction among the learners of English as a Second Language (ESL) with different cultural backgrounds. This study will add to the limited research that has been conducted specifically regarding Japanese learners' preferences for error correction in speaking.

\section{PURPOSE OF THE STUDY}

There has been little information in the literature on Japanese ESL learners regarding their preferences for error correction, and to the 
researcher's knowledge none has dealt with Japanese learners of English as a Foreign Language (EFL). EFL learners may have different attitudes from ESL learners because these two types of learners study in different settings where the learners' levels of exposure to the language differ. In the EFL settings, where learners do not need English to satisfy daily life requirements, there may be a demand for accuracy in English usage, and consequently, their preferences for error correction might be different from those of the learners in ESL settings.

Since English classes in Japanese universities almost always have a large number of students (30 - 60), it would be especially difficult for teachers to modify their expectations and practices in order to cater to each individual student's expectations and needs. However, if successful language learning depends largely on the matching of expectations of teachers and learners, it would be beneficial for the teachers to know the commonly held expectations of their students. When a situation does not allow teachers to modify their expectations, they can minimally include explanations about the rationale behind their expectations as part of their instruction.

This study examined the preferences for classroom oral error correction among university students of English in Japan. It is hoped that the findings of the study will provide both present and future EFL teachers in Japan with useful information for their teaching. 


\section{RESEARCH QUESTIONS}

\section{$\underline{\text { Research Questions }}$}

The following research questions emerged form the researcher's review of the literature on error correction research.

1. What are the general preferences for classroom error correction in speaking among university students in Japan?

2. Do the general preferences for classroom error correction in speaking differ according to students' level of proficiency in the language?

3. What are the general preferences for classroom error correction on different aspects of the language (e.g., pronunciation and grammar) among university students in Japan?

4. Do the general preferences for classroom error correction on different aspects of the language differ according to students' level of proficiency in the language?

5. What are the general preferences for particular types of classroom error correction in speaking among university students in Japan?

6. Do the general preferences for particular types of classroom error correction in speaking differ according to students' level of proficiency in the language?

\section{Hypotheses}

The researcher formulated the following hypotheses based on the literature review and researcher's own experience as an EFL learner in 
Japan.

1. University students of English in Japan have positive attitudes toward teacher correction and negative attitudes toward overcorrection, selective error correction, and peer correction.

2. The preferences for classroom error correction in speaking differ according to students' level of proficiency in the language.

3. The students prefer to have their grammatical errors corrected more than the errors of the other aspects of the language.

4. The preferences for classroom error correction on different aspects of the language differ according to students' level of proficiency in the language.

5. The students most prefer a correction in which the teacher presents the correct response or part of the response, and least favor a treatment in which the teacher ignores errors.

6. The preferences for particular types of classroom error correction differ according to students' level of proficiency in the language. 


\section{CHAPTER II}

\section{LITERATURE REVIEW}

\section{INTRODUCTION}

Correction of errors would seem to be a completely natural part of the language learning process. However, attitudes regarding whether or not to correct errors, which errors to correct, and how to implement corrections have changed considerably since the 1950s when the Audio Lingual Method was widely supported. This chapter begins with a review of the literature on changes in the perception of learner errors followed by a review of the research on error correction and a review of the research on students' attitudes toward error correction.

\section{CHANGING PERSPECTIVES ON LEARNER ERRORS}

Attitudes among language educators regarding the value of error correction have changed a great deal throughout the history of language teaching. The term error correction signifies someone correcting the mistake of another, presumably a teacher correcting a learner (Mings, 1993).

\section{Audiolingualism and Error Prevention}

In the1950s and well into the1960s, error prevention and error 
correction were the major concerns of language teaching. The Audio Lingual Method (ALM) dominated foreign and second language classrooms of that time period. The ALM was conceived from the theories of behavioral psychologists and structural linguists (Larsen-Freeman, 1979). Behavioristic psychologists believed that "language consists of a set of habits in the use of language structures and patterns" (Krashen \& Terrell, 1983, p.14). Habits were constructed through the repeated association between some stimulus and some response, which would become bounded by imitation and repetition. Structural linguists conducted contrastive analyses systematically comparing the first and the target language. The contrastive analysis was applied to predict difficulties in a target language, and to prevent or at least minimize errors (Brown, 1993; Larsen-Freeman \& Long, 1991).

With the Audio Lingual Method, learners spend many hours memorizing dialogues, practicing drills, and studying grammatical rules (Hendrickson, 1978). They are expected to produce flawless utterances in the target language. Brooks (1960), who coined "audiolingualism," notes that "Like sin, error is to be avoided... (p.58), and therefore he suggests quick and explicit error correction. The presumed aim of this teaching method is to train learners to use the target language with fluency and accuracy when communicating with native speakers. However, learners taught with this method are incapable of communicating things that are very different from the memorized patterns and dialogues (Major, 1988). The major criticism of this method is that learners from audio lingual classrooms, which lack communicative activities, need to use the target 
language in communicative situations in order to become fairly proficient in the language. What occurs in most cases is that the majority of the learners fail to use the language in communicative situations, and soon forget most of what they learned in the classroom. The unsatisfactory results of audiolingualism regarding language learning, especially students' communicative competence, led language educators to consider alternative approaches (Hendrickson, 1978).

\section{Developments in the Second Language Acquisition Field}

Changes in the perception of error correction began in the early 1970s. In addition to the increased recognition of the unproductivity of audiolingualism and its behavioristic approach toward error correction, a few other developments in the language acquisition field contributed to the changes (Mings, 1993).

One factor contributing to attitudinal changes toward error correction was Chomsky's (1975) Universal Grammar Theory. Universal Grammar Theory claims that much of language learning is governed by innate abilities to learn language by means of a Language Acquisition Device (LAD). Therefore, obsessive error correction policies of audiolingualism no longer seemed so compelling to language educators (Mings, 1993).

Another factor contributing to changed attitudes toward error correction was the widely supported ideas of Krashen and associates (Krashen and Seliger, 1975). Krashen (1982, 1985a, 1985b) argues that the naturalistic approach can lead learners to mastery of the target language in 
much the same way that children acquire their first language, provided that the learner gets enough exposure to the language. Krashen (1981) terms this process "acquisition" and distinguishes it from "learning" that goes on in the classroom. "Acquisition" is a subconscious and intuitive process of constructing the system of the language. "Learning," in contrast, is a conscious process, which results in a separate system of simple grammar rules, or "knowing about" language. He claims that the conscious learning process and the subconscious acquisition process are mutually independent: learning does not "turn into" acquisition (p.83). He (1985) hypothesizes that acquisition occurs when learners understand language that is heard, not when they produce utterances and focus on form. Krashen (1981) maintains that acquired knowledge initiates utterances. Learned knowledge serves only as an editor, or "monitor," i.e., a mental processor which enables the speakers to correct their utterances before and as they are produced. Krashen (1982) further claims that corrections can take place only when three conditions are met: the learner has time to do so, the learner is focused on form, and the learner knows how to correct errors. In normal face-to-face communication, these conditions can rarely be met. This means that speakers primarily depend on acquired knowledge in spontaneous communication, when they are attending to meaning.

Krashen's Input Hypothesis (1982, 1985a, 1985b) claims that language acquisition occurs through processing "comprehensible input," i.e., "language that contains structure a bit beyond our current level of competence" (1982, p.21). He (1985) further claims that the acquirer needs 
to be "open" (p.3) to the input for acquisition to occur. In explaining this, he uses the concept of an Affective Filter proposed by Dulay and Burt (1977). The 'affective filter' is a mental block that prevents input from reaching the Language Acquisition Device (LAD), i.e., the innate ability to learn language. When this 'affective filter' is 'up', the acquirer may understand the input, but it will not reach the LAD. This occurs when the acquirer is unmotivated, lacking in self-confidence, or anxious. Krashen (1982) claims that overuse of error correction raises the filter, which means that corrected form would not be internalized into the learner's acquired knowledge. In other words, error correction will have no positive effect on oral performance.

\section{Communicative Competence and the Value of Errors}

Developments in interlanguage studies and the emergence of new thinking on second language acquisition led to the emergence of communication as an essential element in second language education. Many researchers and theorists advocated a proposed shift from the Audio Lingual Method to communicative approaches to language teaching (Asher, 1982; Krashen \& Terrell, 1983; Mayer, 1985; Savignon, 1982 among others). Communicative approaches are based on the concept of communicative competence. The term, "communicative competence" was coined by Hymes (1971). Hymes defines communicative competence as the knowledge of grammatical rules as well as the sociolinguistic rules of use. However, some proponents of communicative approaches have interpreted communicative competence to mean that the emphasis should 
be on function rather than form. Therefore they place emphasis on comprehensibility and appropriateness over grammaticality, neglecting learner errors (Major, 1988).

For example, Terrel (1977), a proponent of communicative approaches, maintains that "there is no evidence which shows that correction of speech errors is necessary or even helpful in language acquisition" (p. 330). Krashen (1982), based on the evidence that error correction does not influence first language acquisition to any great extent, claims that error correction has little or no effect on subconscious acquisition. In other words, error correction is not useful for improving second language oral performance. He goes on to say that error correction should be entirely eliminated in communicative-type activities.

In opposition to communicative approaches which neglect error correction, some theorists and researchers argue that the communicative success of erroneous linguistic forms can lead learners to incorporate these forms permanently into their interlanguage (e.g., Corder, 1983; Hammerly, 1987; Higgs and Clifford, 1982; Ke, 1992; Parkin, 1981; Valette, 1991). Selinker (1972) termed this phenomenon "fossilization." He claims that the faulty linguistic forms, unless corrected, are likely to be repeated, and become more strongly incorporated in learners' second language grammar. These theorists and researchers support approaches which encourage learners to produce linguistic structures soon after they are introduced. The teacher systematically corrects the production errors that inevitably result from the learner's imperfect hypotheses about this structure (Selinker, 1972). Rivers (1986) maintains that this hypothesis testing 
procedure is the best way for learners to acquire communicative competence. Further, error correction facilitates learners' hypothesis testing and their interlanguage development (Hendrickson, 1978; Zamel, 1981). Similarly, Omaggio (1983), claims that systematic correction of learners' errors from the beginning of learning will help them make significant progress towards accuracy.

Some other theorists and researchers support the idea that both accuracy and fluency are important for successful communication. They propose a combination of form-focused and function-focused instructions (Brumfit, 1980; Higgs, 1985; Major, 1988; Montgomery and Eisenstein, 1985; Ross, 1981; Widdowson, 1989). Major, for example, stresses that both form and function are important in successful communication because form is an integral part of function. If the form of a certain structure is changed or distorted, the function can also change. Higgs and Clifford (1982) stress that before students engage in communicative activities, students must first have acquired the necessary grammatical rules.

\section{RESEARCH ON ERROR CORRECTION}

While the developments in theories of interlanguage and second language acquisition were evolving, and continuing through the present, a considerable amount of research on error correction was conducted. The studies examined: 1) whether or not to correct errors, 2) when to correct them, 3) what to correct, and 4) how to correct errors. 
Whether To Correct Errors

As mentioned in the previous section, no agreement exists on whether or not to correct learner errors. Hendrickson (1978) and Horner (1988), for example, give an affirmative answer to this question primarily based on the theoretical argument that error correction facilitates learners' hypothesis testing and their interlanguage development.

Allwright (1991) and Sharwood Smith (1991) argue that error correction is useless when it involves a linguistic stage of development that is far beyond the learner's present stage. For instance, 'morpheme studies' (e.g., Dulay and Burt, 1974; Bailey, Madden, and Krashen, 1974) show that the third-person singular s-marker on present tense English verbs is a late-learned morpheme. If a teacher substitutes a learner's use of the unmarked verb with the marked verb, and the learner has no concept of either the form or function of the marked verb, the learner will not be able to internalize the correct form. The teacher, then, will ignore an oral error because error correction will not help speed up the acquisition of the correct form (Allwright, 1991). However, there may be a problem with ignoring oral errors as discussed by Schmidt and Frota (1986). They suggest that an untreated erroneous form may even serve as further input to the learner who uttered it, as well as to the other learners. As a result, the entire class may incorrectly internalize the erroneous form.

Allwright (1991) raises another question which teachers face in deciding whether to treat an error or to ignore it. He believes that it may not seem reasonable to many teachers to 'penalise' (p.100) the learner by correcting an error involving a form or function which has not been 
encountered before. Hammerly (1991) also points out that correcting errors on an unstudied form is a waste of time.

\section{Empirical Studies on Effects of Error Correction}

Chaudron (1986) points out that the answer to the issue of whether or not to correct errors should basically follow from the empirical evidence of the effects of error correction. Although there is little empirical research, some evidence for the positive effects of error correction is provided by the studies of Carroll and Swain (1993), of Chaudron (1977), and of Ramirez and Stromquist (1979). They found that teacher correction of student errors facilitated the acquisition of foreign language grammatical structures. A similar result was observed by Heron (1991) and Heron and Tomasello (1988) who investigated the positive effects of a treatment called the "Garden Path" correction technique. In this treatment, the learners are induced to make an error which is then immediately and clearly corrected by the teacher. The results show that the "Garden Path" learners achieved better performance on the target structures than those who were merely given the correct information.

A counter-finding against the positive effect of error correction was found by Carrol and Swain (1992). They conducted a laboratory study with English-speaking university students learning French as a second language. They investigated the effect of error correction on the learning of two morphological generalizations. They found a positive short-term effect of feedback in helping the learners to remember what suffix is attached to a specific stem. However, they found no evidence that learners in the 
feedback group induced the suffixation rule better than learners in the control group.

Another research finding supports the idea that error correction has no positive effect on oral performance. Dekeyser (1993) attempted to assess the effect of oral error correction on oral proficiency and grammar knowledge using native speakers of Dutch. As the researcher expected, the results of the study showed that error correction did not have a significant overall effect on student proficiency or achievement.

Imai (1989) also reports a finding that does not support the positive effect of error correction on oral performance. In her study, error correction did not show significant effect on oral performance.

These contradictory findings suggest that the question of whether or not to correct errors is not a simple matter.

\section{Individual Differences}

In deciding whether to correct learner errors, leaners' individual differences may be one of the important factors to be taken into account. Dekeyser (1993) and Major (1988) point out that one reason for the lack of agreement on the effects of error correction may be largely because of individual learner differences, such as personality variables, learning strategies, aptitudes, and learners' attitudes toward being corrected.

Meisel, et al. (1981) discuss the learners' diverse preferences. They claim that learners who display a predominantly "simplifying" orientation favor communicative effectiveness, and those who have a predominantly "standard" orientation favor accuracy (Pienemann et al., 1988, p.222). This 
means that error correction may not have a positive effect on the learners who prefer communicative effectiveness.

Cultural background may also affect the preference toward error correction, which may influence the effects of error correction. Cohen (1975) notes that public error correction may not be profitable for students from "cultures in which the learner performs a new skill only after he has perfected it in private" (p.418). Similarly, Major (1988) suggests that learners who are from a culture that seldom corrects an individual would tend to have a negative reaction toward being corrected.

Language aptitude is another individual student characteristic that may influence the effect of error correction on learners' spoken errors. For instance, there is no doubt that some learners can mimic well while others cannot. As Purcell and Suter (1980) note, aptitude for mimicry appears to be beyond the control of the instruction. Thus, it should be noted that error correction may have no positive effect on errors of learners with low aptitude for mimicry.

One other individual student variable that may affect the effectiveness of error correction is foreign language anxiety. Foreign language anxiety is described as a high feeling of self-consciousness, fear of making mistakes, and a desire to be perfect when speaking (Horwitz et al., 1986). Foss and Reitzel (1988) note that the learners with strong foreign language anxiety typically have low self-esteem and perceive themselves as inferior to others. They also perceive their communication as less effective than that of their peers, and "expect continued failure no matter what feedback they actually receive" (p.439-440). They conclude that error 
correction creates more anxiety in learners with low self-esteem, and therefore has no positive effects.

Considering all the factors which may affect the efficacy of error correction, as well as the empirical evidence on the effects of error correction, the question of whether to treat errors appears to have no agreed answer.

\section{When To Correct}

The most difficult challenge of language teaching is to determine when to correct and when to ignore learner errors (Gorbet, 1974). As the review of literature on error correction reveals, many second and foreign language educators have rejected the obsessive error elimination that characterizes audiolingual approaches to language teaching (Corder, 1967; Hendrickson, 1976; Holly and King, 1971; Krashen and Seliger, 1975; Terrell, 1977 among others). Hendrickson (1978) notes that tolerating some errors may help learners use the target language more confidently, and suggests that error correction should be restricted more to "manipulative grammar practice," (p.390) leaving communicative activities free from an emphasis on error correction. Teachers generally agree with this idea, and do not treat all the errors that do occur, as observed in the studies on teacher treatment of learner error (Allwright, 1975; Chaudron, 1977, 1986; Fanselow, 1977; Long, 1977; and Nystrom, 1983).

Allwright (1991) also discusses the question of when to treat an error. The teacher may treat it immediately, or delay the treatment until the learner finishes his or her utterance. Alternately, the teacher may 
postpone the treatment for longer periods of time. The psychology research literature shows that feedback becomes less effective as the time between the performance of the skill and the feedback increases (Long, 1977). Allwright points out that immediate error treatment often involves interrupting the learner in mid-sentence, which could eventually suppress the learners' desire to continue communication. Vigil and Oller (1976) term this practice "the negative affective feedback" (p.186). They claim that positive affective feedback is essential because one of the first requirements for meaningful communication is an affective affirmation of the other person. There is little classroom research regarding the comparative value of immediate, delayed, or postponed feedback. Allwright therefore suggests that teachers and researchers must make their own decision based on the observation of the results of implementing these types of treatments.

\section{Which errors to Correct}

Burt and Kiparsky (1972) classify language learner errors into two categories: "global" errors, i.e., errors that cause a listener or reader to misunderstand a message or to consider it incomprehensible; and "local" errors, i.e., errors that do not significantly inhibit communication. Burt (1975) claims that correcting one global error in a sentence makes the intended message clearer than correcting several local errors in the same sentence. This sounds convincing and there does seem to be agreement that "global" errors are most serious (Hughes and Lascaratou, 1982). A number of language educators also suggest that errors that interfere with the meaning of a message should receive top priority for correction (e.g." 
Fanselow, 1977; Hanzeli, 1975; Hendrickson, 1978; Powell, 1975).

What then interferes with the meaning of a message? Chun et al. (1982) investigated error correction in native speaker-nonnative speaker conversations in social settings. The result shows that errors of a factual nature were most often treated, followed by discourse and vocabulary correction. Grammatical errors were seldom treated. In his study of teacher correction of oral errors in classroom, Fanselow (1977) also found that the error type least likely to be treated was grammatical errors. From the results of the research on a French immersion program, Chaudron (1986) found that most teachers treated content errors more than linguistic or phonological errors.

Another category of errors which many researchers believed should be corrected are those that stigmatize the learner from the perception of native speakers (Sternglass, 1974; Corder, 1975; Hanzeli, 1975).

A number of educators suggest that errors which occur frequently should be among the first errors to be corrected (Allwright, 1975; Holley \& King, 1971). Cohen (1975) suggests that errors relevant to the objectives of a particular lesson deserve to be corrected.

\section{How to correct errors}

The issue of how to correct learner errors is another complex and important question. Holley and King (1971) suggest that teachers should avoid using correction techniques that might embarrass or frustrate students. One polite way of letting students know that they have committed errors is by asking for repetition of their utterances, for 
example, "What"? or "Would you please repeat that"? With this implicit correction, the student would not feel like he or she was directly being corrected, and thus would save face.

This approach, however, might be often ambiguous because the student may have difficulty in telling whether the teacher did not hear what he or she has just said or simply is trying to elicit self-correction (Chaudron, 1977; Cohen, 1975).

Holley and King (1971) found that when teachers waited five to ten seconds after students hesitated, the students self-corrected over $50 \%$ of the time. They suggest that if wait-time alone does not elicit a correct student response, then rephrasing of the question, cuing the student with a word or phrase, or providing a full or partial sample sentence might give the necessary stimulus. Corder (1967) also supports the idea that teachers should just prompt rather than supply a correct response.

One way for the teacher to indicate that an error has been committed is by using gestures, for example, shaking head sideways, grimacing, or keeping an eye open for puzzled expressions (Fanselow, 1977; Horner, 1988; Sharwood Smith, 1991). Another method to elicit self-correction is a technique in which the teacher repeats the last correct word in the student's utterance, and waits for self-correction (Horner, 1988). Schachter (1981) proposes a set of hand signals for teachers to use in order to alert a student to the presence of an oral error and its type. Hand signals form various letters for certain error types, such as a " $\mathrm{P}$ "which indicates an incorrect preposition.

Cathcart and Olsen (1976) surveyed ESL teacher's actual methods in 
correcting student's conversation errors. Of a total of 132 cases of corrections on video tape, corrections most frequently used by the 21 teachers were the methods of 'giving correct model' followed by 'giving a partial model by pinpointing the area of error,' 'repeating the erroneous form with rising intonation (e.g., "Go"?),' 'comparison of error and model,' and 'giving explanation.'

Fanselow (1977) investigated how experienced ESL teachers responded to errors in their classrooms. He found that the most popular response was the method of 'giving the correct model' and 'giving part of correct model.' Nystrom (1983) also reports that the ESL teachers in her study often used the correction method of 'giving the correct model.'

In the study by Fanselow (1977), 'ignoring errors' was another method which was used as frequently as 'giving correct model' and 'giving part of correct model.' Other popular methods in this study were 'asking for repetition of the utterance,' and 'saying "no" followed by repeating the erroneous form.'

\section{Who Should Correct Errors}

Although the literature on self-correction and peer correction of written errors is plentiful, little research or discussion has been conducted regarding oral errors. Allwright (1975) notes that the teacher is expected to be a source of information about the target language and to treat errors when appropriate. Cohen (1975) claims that teacher correction alone is probably not sufficient and may not alter the student's error patterns very noticeably. He hypothesizes that student self-correction and peer correction 
may contribute more to eliminate errors than teacher correction. He further maintains that peer correction might also improve the students' ability to recognize errors.

Bruton and Samuda (1980) studied peer correction of oral errors when ESL students were involved in a variety of problem-solving tasks. The students were videotaped over a period of one week. The teacher did not intervene during the tasks. The students corrected each other successfully, even though they had not been advised to do so. In addition, they employed various treatment types. In this study numerous instances of self-correction were also observed.

\section{RESEARCH ON STUDENTS' ATTITUDES TOWARD ERROR CORRECTION}

Oladejo (1993) notes that the viewpoints of teachers and classroom practice regarding error correction do not always match the needs and expectations of learners. Such mismatch could cause lack of success in language learning. He claims that teachers should try to analyze learners' needs and expectations. This section deals with a review of literature on the research on students' attitudes toward error correction.

\section{Whether or not to correct errors}

In adult second and foreign language acquisition, there may be strong egos and high levels of affective filter. Ke (1992) cites the study by You (1991) in which while the majority of the students had positive attitudes toward their teachers' correction of their oral errors, slightly more 
than one third of the students reported negative feelings about their teachers' classroom error correction. Ke claims that teachers should be aware of students' negative emotional reactions to their teachers' inclass error correction. Effectiveness of error correction would largely depend on the learners' attitudes toward error correction (Cathcart and Olsen, 1976).

Cathcart and Olsen surveyed the preferences of 188 adult ESL learners for oral error correction. They reported that the learners showed a strong preference for correction. A recent survey by Oladejo (1993) also found general agreement among 500 EFL adult learners with the view that teachers should correct students' errors in order to enhance their fluency and accuracy in the language.

A study by Chenoweth et al. (1983) of 418 adult ESL learners' attitudes toward interaction with native-speaking friends also found positive attitudes toward error correction. These learners regard error correction as "facilitating" the improvement of their oral performance, or even "being necessary" for it (p.85). Interestingly, the Korean students in the survey did not have significantly positive attitudes toward error correction. Chenoweth et al. suggest further study on factors of ethnicity and culture.

\section{When to correct errors}

As observed in the studies on teacher treatment of learner error, it appears to be widely believed that selective error correction is desirable because constant error correction frustrates learners (Allwright, 1975; Chaudron, 1977, 1986; Fanselow, 1977; Long, 1977; and Nystrom, 1983). A 
study by Walker (1973) also supports the idea that teachers should tolerate some learner errors. He conducted a survey of 1200 university students of foreign language partly to investigate attitudes toward having their errors corrected by their teachers. The students preferred not to have each minor error corrected because they felt this practice destroyed their confidence, and forced them to lose the overall ability to use language because of excessive attention to details.

Contrary to the results of Walker's study, some other studies mentioned earlier found that students prefer more correction than their teachers actually did (Cathcart \& Olsen,1976; Chenoweth et al., 1983; Oladejo, 1993)

Approximately $59 \%$ of the ESL students in the study by Cathcart and Olsen (1976) indicated that they "wished to be corrected all the time" (p.45). The study by Chenoweth et al. (1983) of 418 adult ESL learners' attitudes toward interaction with native-speaking friends also found a strong preference for more error correction.

The majority of the $500 \mathrm{EFL}$ adult learners in the study by Oladejo (1993) disagree with the current belief that teachers should focus only on errors which inhibit communication. The majority of the students also disagree with the notion that constant error correction frustrate learners and discourage them from using the language. The majority of the learners in the study wanted to have their errors 'always' corrected, namely, errors of organization of idea, grammar, and vocabulary. 
Which errors to correct

As a review of literature on teachers' treatment of errors reveals, teachers seldom correct grammatical errors (e.g., Chaudron, 1986; Fanselow, 1977). Interestingly, language learners appear to have different preferences for priorities of error correction than do language educators. In the adult ESL classrooms, students reported they prefer explicit correction of their errors, especially pronunciation and grammar errors (Cathcart and Olsen, 1976). Oladejo (1983) also found that the 500 ESL learners believe that errors relating to organization of ideas and grammatical errors should receive the highest attention for correction.

\section{How to correct errors}

As observed in the studies by Fanselow (1977) and by Cathcart and Olsen (1976), techniques in which teachers elicit learners to self-correct were popular among teachers. Kasper (1985) investigated repair in the EFL classroom by videotaping a class. She defines repair as "modifications of trouble sources which have manifested themselves in the discourse" (p.200). Kasper's data shows that learners favored "self-completed repair" (p.200) i.e., the producer of the error self-corrects it. She points out that selfcorrection is preferable because it gives the learner a chance to maintain face, and provides the teacher with information on the learner's proficiency. Techniques which encourage learners to self-correct are also favored by the students in the study by Cathcart and Olsen (1976). Similar findings were observed in the Oladejo's study (1988). His learners' most preferred a method in which the teacher provided hints that might enable 
the learners to self-correct.

A correction method in which teachers provide students with correct models is another popular method among teachers (Fanselow, 1977; Nystrom, 1983). The learners in the study by Cathcart and Olsen (1976) also most favored this method, followed by "comparison of errors and model" and providing "explanation" (p. 47). The least preferred method among the learners in the study by Cathcart and Olsen was ignoring errors. The students in the study by Oladejo (1993) also expressed little or no preference for this method. Ignoring errors was also least preferred by the teachers in the study by Cathcart and Olsen. Interestingly, however, the teachers in the study by Fanselow (1977) frequently ignored their students' errors, which differs from the findings of the above stated studies. As Fanselow suggests, it would be beneficial to ask teachers and students about the types of treatments they prefer and the reasons they like them.

Cathcart and Olsen also observed the major differences between the students and the teachers regarding the preferences for error correction types. For grammar errors, the students preferred "comparison of error and model" more than the teachers did. On the other hand, the teachers preferred the correction, "giving a partial model by pinpointing the area of error (Yesterday, I...)" more than the students did (p.47).

Another interesting finding that Cathcart and Olsen observed was that all nationalities except Latin Americans and Japanese chose "Don't say go; say went (comparison of error and model)" as one of the three most liked corrections. Cathcart and Olsen note that Latin Americans and Japanese like negative-sounding corrections less than other nationalities. 
They point out that the small size of several of the cultural groups made it difficult to generalize their attitudes, and suggest further research on ethnic preferences for different types of correction with larger sampling of these cultural groups.

As the findings of the above mentioned research show, there appear to be important differences between the views and practice of linguists and teachers on the one hand, and learners' preferences and expectations on the other. Certain important differences were also observed in the preferences of learners at different levels of English proficiency, as well as of learners from different cultures.

Oladejo (1993) suggests that whether or not to correct learner errors, when to do so, which errors to correct, and how to correct them should not depend on what language educators think but on learners' preferences and expectations. He claims that the best decisions on these issues can be made only by analyzing the needs and expectations of the learners with careful consideration given to the ESL/EFL cultural background and the learners' level of English proficiency. Oladejo further maintains that teachers should be flexible enough to modify their beliefs and practices about error correction where necessary.

\section{SUMMARY}

Views among foreign and second language educators regarding the value of error correction have considerably changed in recent decades. Errors are no longer viewed negatively, and are regarded as a natural 
phenomenon essential to the process of language learning. However, there appears to be no general consensus among language educators on whether or not to correct errors. The questions of when to treat errors, which errors to correct, and how to implement corrections are also complex and important. There seems to be no agreement regarding these questions among educators. There also seem to be diverse preferences between learners and their teachers regarding the correction of oral errors. Some researchers suggest that language teachers should analyze and try to meet the needs and the expectations of the learners in order to develop their positive attitudes toward what they are learning. 


\section{CHAPTER III}

\section{METHOD}

\section{INTRODUCTION}

This chapter describes the methods employed in this study. The chapter is divided into four sections. The first section describes the subjects of this study. The second section presents the data collection instrument. The third section describes the procedures of translation, pilot studies, and data collection, and an outline of statistical procedures used for data analysis.

\section{SUBJECTS}

The purpose of this study was to investigate the preferences for classroom error correction among university students of English in Japan. For this purpose, the subjects of this study were undergraduate students of English in Japanese universities ranging in the level of proficiency from elementary to advanced. The subjects had studied English at least six years at the junior high and high school level.

The sample for this study consisted of 588 students from twenty-one English classrooms at six universities located in three different cities in 
Japan. Attempts to obtain a random sample, which is considered to be representative of the population of a study from which it is selected, were not feasible for this study. Thus a non-random sample was selected for this study. However, the sample of this study did provide a varied population mix, which increased the degree of representativeness of the target population.

Subject recruitment was accomplished through the cooperation of the researcher's associates who are professors in Japanese universities. The professors agreed to allow the researcher to administer questionnaires to their students. The professors also recruited additional professors and teachers who agreed to allow the researcher to conduct surveys in their classes. The researcher also obtained cooperation of several professors who volunteered to distribute questionnaires among their students.

\section{INSTRUMENT}

\section{Questionnaire}

A questionnaire was developed as the instrument for this study. It utilized information obtained from an extensive literature review. The content of the questionnaire was intended to elicit information on English learners' preferences for classroom oral error correction.

A professor in the Department of Sociology at Portland State University, who is a statistical expert, reviewed and evaluated the instrument in terms of its validity and format. From his input, the instrument was rewritten. The questionnaire was revised several times 
based on input from this professor and the members of the thesis committee, and from the results of the pretests discussed in the following section.

The questionnaire contains four sections, the first relating to demographic information, the second asking about the respondents' general views about classroom oral error correction, the third asking about their preferences for classroom corrections of speech errors on different aspects of English, and the fourth asking about their preferences for particular types of error correction in speaking.

While open-ended questions can be useful for gathering qualitatative information, responses to closed-ended questions are easier to collate and analyze (Johnson, 1992; Nunan, 1993). Therefore, closed-ended questions were chosen in preference to open-ended questions except for several demographic questions and a few questions to identify the reasons for the respondents' choices.

The first section consisted of questions to collect individual subjects' demographic information such as major of study, gender, length of stay in an English-speaking country, and whether or not they had opportunities to speak English outside of the classroom. These last two questions aimed to discover the respondents' levels of exposure to the spoken English of native speakers. This rationale was based upon the assumption that the experience of interaction with native speakers may influence the opinions of English learners regarding error correction.

In the same section of demographic questions, respondents were asked to self-rate their oral communication skills in English. According to 
information that the researcher obtained from the respondents' teachers, each class was composed of students with diverse levels of oral proficiency. Thus the class level alone (e.g., English Conversation I - Elementary) could not be a reliable source of assuming a respondent's oral proficiency. As one of the solutions to this problem, one could suggest scores of standardized tests, such as TOEFL (the Test of English as a Foreign Language), in order to assess respondents' proficiency of the language. However, TOEFL scores may not accurately predict test-takers' oral proficiency because the TOEFL assesses "the ability to understand recorded and written English, as well as the ability to identify correct/incorrect structural form," (Reed, 1992, p.330) but not oral language use. In addition, it seemed infeasible to require the respondents to take TOEFL tests for the sake of the present study especially because of time and expense involved with the test. Therefore, selfassessment was determined to be the most practical and appropriate method to assess respondents' speaking abilities. Although self-assessment does have some limitations, it still provided the researcher with the learners' personal view regarding error correction based upon their perceived proficiency levels.

In the present study, a set of descriptions of communication tasks (Appendix A) were employed for self -assessment instead of a Likert scale (e.g., poor-fair-average-good-very good). The researcher believed that the descriptions might provide respondents with information that would lead to greater objectivity than simply a Likert scale. A list of descriptions, which illustrated the abilities for global tasks or functions, was developed based on the generic descriptions in the ACTFL (American Council on the 
Teaching of Foreign Languages) Proficiency Guidelines (Byrnes and Thompson, 1989). The ACTFL Proficiency Guidelines was developed for the ACTFL's Oral Proficiency Interview (OPI). The OPI aims at global assessment of functional speaking ability, or oral proficiency.

The respondents were asked to check all the descriptions of the communication tasks that they thought they could perform in English (e.g., "I can exchange greetings." and "I can debate on social and current topics."). The ACTFL rating scales range from Novice Level to Superior Level. The respondents rated at the Novice Level were categorized as Elementary in this study, and Intermediate Level respondents as Intermediate. Those who were rated as Advanced Level and Superior Level were categorized as Advanced.

Levels were computed based on individual respondents' answers to each question item. The question items 7 -a through 7-c indicate the speaking ability of Elementary Level, 7-d through 7-k indicate Intermediate Level, 7-1 through 7-q indicate Advanced Level. 7-r, which characterized Superior Level on the ACTFL scale, was categorized as Advanced Level in this study. Rating criteria of the ACTFL OPI include: "Only sustained performance of the tasks required at a level suffices for being rated at that level," and "Each major level subsumes the criteria of the levels below it" (Byrnes and Thompson, 1989, p.4). More specifically, OPI test-takers need to be able to perform all the tasks required at a specific level in order for them to be rated at that level. This criterion was considered to be inappropriate for the present study because it does not take into account the lower range of each level (e.g., low advanced level and low intermediate level). The 
researcher set the criterion that respondents would need to perform half or more of the tasks required at a specific level in order for them to be rated at that level. From this criterion, the number of the students who were assessed as Advanced based upon their self-rating on the communication tasks was roughly similar to that reported as "advanced" by their teachers. A similar comparison for the elementary and intermediate levels was not able to be completed because the teachers did not provide comprehensive demographics about their students. The teachers simply described their students' levels as, e.g., "Some of my students are in elementary level and some are in intermediate level." or "The students in this class are ranged in level from upper basic to intermediate."

Based on the researcher's criterion, respondents who checked half or more of the items between 7-1 and 7-q were rated as Advanced. Those who checked half or more of the items between 7-d and 7-k, and did not meet the criterion for Advanced level, were rated as Intermediate. Respondents who neither met the criteria for Advanced level nor Intermediate level were rated as Elementary.

The second section of the questionnaire asked the respondents' opinions about the classroom correction of learners' spoken errors. The section consisted of four questions, and each question included a statement. These statements illustrated the views which have been controversial among linguists and language teachers for decades. These views included: whether or not learner errors should be corrected, when learner errors should be corrected, (i.e., constantly or selectively), and who should correct errors. The participants were asked to rank one of the five choices by using 
five-point Likert scales that ranged from "strongly disagree" to "strongly agree." This section is linked to research questions: 1) What is the general preferences for classroom error correction in speaking among university students in Japan? and 2) Do the general preferences for classroom error correction in speaking differ according to students' level of proficiency in the language?

The third section of the questionnaire asked the participants how often they favored classroom error correction on different aspects of the language: grammar, phonology, vocabulary, pragmatics, and discourse. Since the direct translations of the terms, "phonology," "pragmatics," and "discourse," were thought to be too difficult for the subjects, the researcher determined to present examples. In indicating "phonology," the examples,"pronunciation, accent, and intonation," were presented.

Errors in "pragmatics" were presented as inappropriate expressions (e.g., When offering a drink, "Would you like some coffee"? is more appropriate than "Do you want to drink coffee"? ). Mey (1993) defines pragmatics as "the study of the conditions of human language uses as these are determined by the context of society" (p. 42). Because pragmatics relate to societal and cultural meanings, the foreign language learner is susceptible to making pragmatic errors. Some pragmatic errors concern inappropriate "speech acts," i.e., acts that accomplish a goal through the use of language. Examples of speech acts are requesting, refusing, apologizing, and so on. How a speaker accomplishes a given speech act is determined by contextual features (e.g., status of speaker and listener, relationship between speaker and listener, their gender, their ages, etc.) (Larsen- 
Freeman \& Long, 1994). In second language learning, pragmatic errors in speech acts might be caused by a transfer of pragmatic habits of the learner's first language: rules and norms of the learner's first language which are "language"-specific and those which are "culture"-specific (Riley, 1989, p. 235).

In the questionnaire, "discourse" was presented as: organization of discourse (e.g., how to negotiate or persuade). Discourse errors indicate errors beyond the sentence level. Examples include inappropriate opening and closings of a conversation, inappropriate refusal, incorrect topic nominations or switches, and so on (Chun et al., 1982). A learner's first language affects culture-specific aspects of the second language at the discourse level. These aspects include: 1) the length or amount of discourse time and/or space generally used to employ conversational features, 2) the frequency with which conversational features are used, 3) the sequential ordering of conversational features (i.e., the time and/or place in the conversation in which conversational features appear), and 4) the function of conversational features (Scarcella, 1992). These types of errors in discourse might occur in the conversations of second language learners.

In the questionnaire, the respondents were asked to rank estimated frequency of each item (e.g., pronunciation and grammar) using five-point Likert scales, ranging from "never" to "always." This section is linked to research questions: 3) What are the general preferences for classroom error correction on different aspects of the language (e.g., pronunciation and grammar) among university students in Japan? and 4) Do the general 
preferences for classroom error correction on different aspects of the language differ according to students' level of proficiency in the language?

The last section of the questionnaire asked the respondents' opinions about particular types of classroom error correction in speaking. In the questions, the types of error correction in the questions were chosen based on a review of the literature about teacher practice of error correction and on student reaction to error correction. These correction types were either significantly favored or disliked among the learners in the studies that the researcher reviewed. The perceived value of each item were ranked by the participants using five-point Likert scales ranging from "not good" to "very good." This section is linked to research questions: 5) What are the general preferences for particular types of classroom error correction in speaking among university students in Japan? and 6) Do the general preferences for particular types of classroom error correction in speaking differ according to students' level of proficiency in the language?

\section{PROCEDURES}

\section{Translation Procedure}

The original questionnaire was constructed in English, and translated into Japanese by the researcher under supervision of an American professor and a Japanese professor who are both currently teaching Japanese in the Department of Foreign Languages and Literatures at Portland State University.

A questionnaire written in Japanese was employed for this study 
based on the assumption that subjects would understand the content of the questionnaire more accurately and quickly in Japanese than in English. The external review of the original and translated questionnaires were provided by a Japanese Ph. D. candidate currently teaching Japanese at a college in Oregon and by a Japanese graduate student currently enrolled in the Department of Applied Linguistics. The final review was provided by a native-speaking professor of Japanese who is currently teaching Japanese in the Department of Foreign Languages and Literatures at Portland State University. The questionnaire in English and its Japanese version are included in Appendices A and B.

\section{Pilot Testing}

The questionnaire was pretested to discern deficiencies and necessary improvement. Forty Japanese students of Otemae Women's College, who had been studying English at PSU were asked to complete the questionnaire and identify weaknesses in August, 1995. The purpose of the pretest was to determine if the questionnaire items were understandable, whether five-point Likert scales were appropriate to administer, and whether there were any irrelevant or missing question items. The participants were asked to write down comments and suggestions after filling out the questionnaire. The questionnaire was rewritten based on the results of the pretest, in which confusion arose regarding ambiguous, difficult terms and expressions.

The revised questionnaire was pretested to identify further weaknesses on sixteen Japanese undergraduate students at PSU in 
September, 1995. One of the main purposes of this pretest was to determine if the completion of the revised questionnaire would take no longer than fifteen minutes. Fifteen minutes was chosen as the appropriate length of time without interrupting the ninety-minute classroom instruction time. The pretest also aimed at determining if some of the open-ended questions needed to be compulsory for the purpose of this study. These open-ended questions were designed to identify the reasons for respondents' choices on five-point Likert scales. The observation of this pretest revealed that some of the respondents spent more time than expected on these open-ended questions, and did not spend as much time on the rest of the questionnaire. A few answers to the open-ended questions were essentially irrelevant to the researcher's intent. These compulsory open-ended questions were altered to be optional because they were not crucial for the purposes of this study. Some other modifications were made to the questionnaire based on the pretest. For example, demographic questions were reexamined, and less irrelevant questions for this study were deleted to shorten the time for completion of the questionnaire. In addition, some of the terms and expressions were altered based on the respondents' written comments/suggestions. This version was administered to the subjects of this study.

\section{Data Collection}

Through the cooperation of the researcher's associates who are American professors of Japanese universities, she obtained permission to administer the questionnaire in the classes from professors and teachers at 
six universities located in three different cities in Japan. The researcher herself distributed the questionnaire to students of English at these universities in January, 1996. Some professors and teachers volunteered to distribute the questionnaire to their students in January and February, 1996. All the subjects were asked on a voluntary basis to complete the questionnaires during their class time period. In all classes, the subjects were given approximately 15 minutes to complete the questionnaire.

The researcher went to the designated classes on the days approved by the professors and teachers. In most of cases, the researcher administered the questionnaire at the beginning of class. The professors and teachers briefly introduced the researcher as a graduate student from the Department of Applied Linguistics at Portland State University. After the introduction, the researcher stated her name, clarified the purpose of the survey, explained the consent form, and informed them that participation was voluntary. The researcher distributed the folded questionnaire with the consent form as the first page. Additionally, a copy of the consent form was inserted for the students' own records.

A consent form which included identification of the researcher and a brief summary of the research project. The consent form also included statements that: the research was not being conducted by the subjects' universities; their answers to the questionnaire would not affect their grades at all; all information given would be kept confidential; all information from this study would be dealt with as group data; the results of the study might be utilized by their teachers; the subjects would not be asked to attach their names in the questionnaires; their participation would 
be voluntary; they would be free to leave any answers blank, or discontinue participation in the study at any time; those who had decided not to participate in the survey could turn in a blank questionnaire, and leave the class; and the completion of the questionnaire would take approximately 15 minutes.

From the Japanese researcher's own experience that Japanese people are not accustomed to signing consent forms before answering questionnaires, the subjects were asked to indicate their consent to participate in this study by circling "yes" or "no" and put the date. All the subjects were given a separate copy of the consent form to be kept for their future reference.

\section{Data Analysis}

Data from each questionnaire was entered using Claris Works, and analyzed using the statistical software program named JMP. The program calculated frequency distributions. The Kruscal-Wallis tests were employed to examine the significance of the hypothesized differences among groups. As is conventional in language studies, the significance level for all statistical tests was set at 0.05 . 


\section{CHAPTER IV}

\section{RESULTS OF SURVEY QUESTIONNAIRE}

\section{INTRODUCTION}

This chapter presents the results of the data analysis of the responses to the survey questionnaire. Data are presented in the form of figures and tables which display percentages. The description of results parallels the four sections of the questionnaire. The first part provides a summary of the demographic information about the respondents of the survey. The second part describes the results of the respondents' attitudes toward the views about correction of oral errors which have been controversial among linguists and teachers for decades. The third part shows the results of the respondents' preferences for error correction on different aspects of the language, e.g., grammar and phonology. The fourth part illustrates the results of the respondents' preferences for methods of error correction. In each part, differences regarding the respondents' preferences were analyzed among the three groups of students (Elementary, Intermediate, and Advanced). The last part discusses differences in preferences between subgroups, such as gender and academic major fields. 
PART ONE: DEMOGRAPHIC DATA

Section A of the questionnaire elicited demographic data from the respondents (Appendix A). Table I depicts a summary of this information.

Five hundred and eighty-eight subjects responded to the questionnaire. The respondents were from six universities: Hiroshima City University $(17,2.8 \%)$, Hiroshima University $(274,46.7 \%)$, Hiroshima University of Economics (5, 0.8\%), Kyoto University of Foreign Studies (65, $11.1 \%)$, Nagoya University (100, 17.0\%), and Ryukoku University (127, $21.6 \%)$. Regarding gender, 233 respondents (39.8\%) were male and 353 $(60.2 \%)$ were female, and 2 did not indicate their gender. Regarding major fields, $92(15.6 \%)$ were majoring in English as a foreign language; the rest were in English literature $(139,23.6 \%)$ economics $(77,13.1 \%)$, education $(98$, $16.7 \%)$, foreign languages $(22,3.7 \%)$, medicine $(23,3.9 \%)$, and others (137, $23.0 \%)$. One hundred and seventy-one $(29.1 \%)$ respondents were rated as Elementary level of proficiency, 363 (61.7\%) were Intermediate, and 54 $(9.2 \%)$ were Advanced.

When asked whether they wanted to improve their speaking skills in English, 566 (96.4\%) said yes, 21 (3.6\%) said no, and 1 gave no response. When asked whether they had opportunities to speak English outside of the classroom, $82(14 \%)$ reported yes, and $506(86 \%)$ reported no. When asked how long they had lived in an English-speaking country, $110(18.7 \%)$ reported that they had lived in an English-speaking country for one month or more, and $478(81.3 \%)$ had lived in an English-speaking country for less than one month or not at all. 
TABLE I

DEMOGRAPHIC DATA OF RESPONDENTS

\begin{tabular}{|c|c|c|}
\hline & & FREQUENCIES \\
\hline \multirow[t]{6}{*}{ UNIVERSITY } & Hiroshima City University & $17(2.8 \%)$ \\
\hline & Hiroshima University & $274(46.7 \%)$ \\
\hline & Kyoto University of Foreign Studies & $65(11.1 \%)$ \\
\hline & Nagoya University & $100(17.0 \%)$ \\
\hline & Ryukoku University & $127(21.6 \%)$ \\
\hline & Hiroshima University of Economics & $5 \quad(0.8 \%)$ \\
\hline \multirow[t]{7}{*}{ MAJOR FIELD } & English Literature & $139(23.6 \%)$ \\
\hline & English As a Foreign Language & $92(15.6 \%)$ \\
\hline & Education & $98(16.7 \%)$ \\
\hline & Economics & $77(13.1 \%)$ \\
\hline & Foreign Languages & $22 \quad(3.7 \%)$ \\
\hline & Medicine & $23 \quad(3.9 \%)$ \\
\hline & Others & $137(23.4 \%)$ \\
\hline \multirow[t]{2}{*}{ GENDER } & Male & $233(39.8 \%)$ \\
\hline & Female & $353(60.2 \%)$ \\
\hline \multirow[t]{3}{*}{ PROFICIENCY LEVEL } & Elementary & $171(29.1 \%)$ \\
\hline & Intermediate & $363(61.7 \%)$ \\
\hline & Advanced & $54 \quad(9.2 \%)$ \\
\hline \multirow[t]{2}{*}{ DESIRE TO IMPROVE ENGLISH } & Yes & $566(96.4 \%)$ \\
\hline & No & $21 \quad(3.6 \%)$ \\
\hline OPPORTUNITIES TO SPEAK & Yes & $82(14.0 \%)$ \\
\hline ENGLISH OUTSIDE OF CLASS & No & $506(86.0 \%)$ \\
\hline EXPERIENCE OF LIVING IN AN & 1 month or more & $110(18.7 \%)$ \\
\hline ENGLISH-SPEAKING COUNTRY & less than 1 month or none & $478(81.3 \%)$ \\
\hline
\end{tabular}


PART TWO: PREFERENCES FOR CORRECTION OF ORAL ERRORS

\section{Preferences for Teacher Correction of Oral Errors}

Section B of the questionnaire (Appendix A) attempted to examine subjects' views about error correction. The respondents were asked whether or not they agreed with a statement, "I want teachers to correct my errors in speaking English." The rating for how they agreed or disagreed with the statement was measured on a five-point Likert scale ( $1=$ strongly disagree, $5=$ strongly agree). Results showed that most respondents had strong positive attitudes toward correction of errors in speaking English. The majority (455 responses, 77\%) wanted their spoken errors corrected, and the minority (32 responses, 5.4\%) did not. Figure 1 depicts the frequencies of the responses.

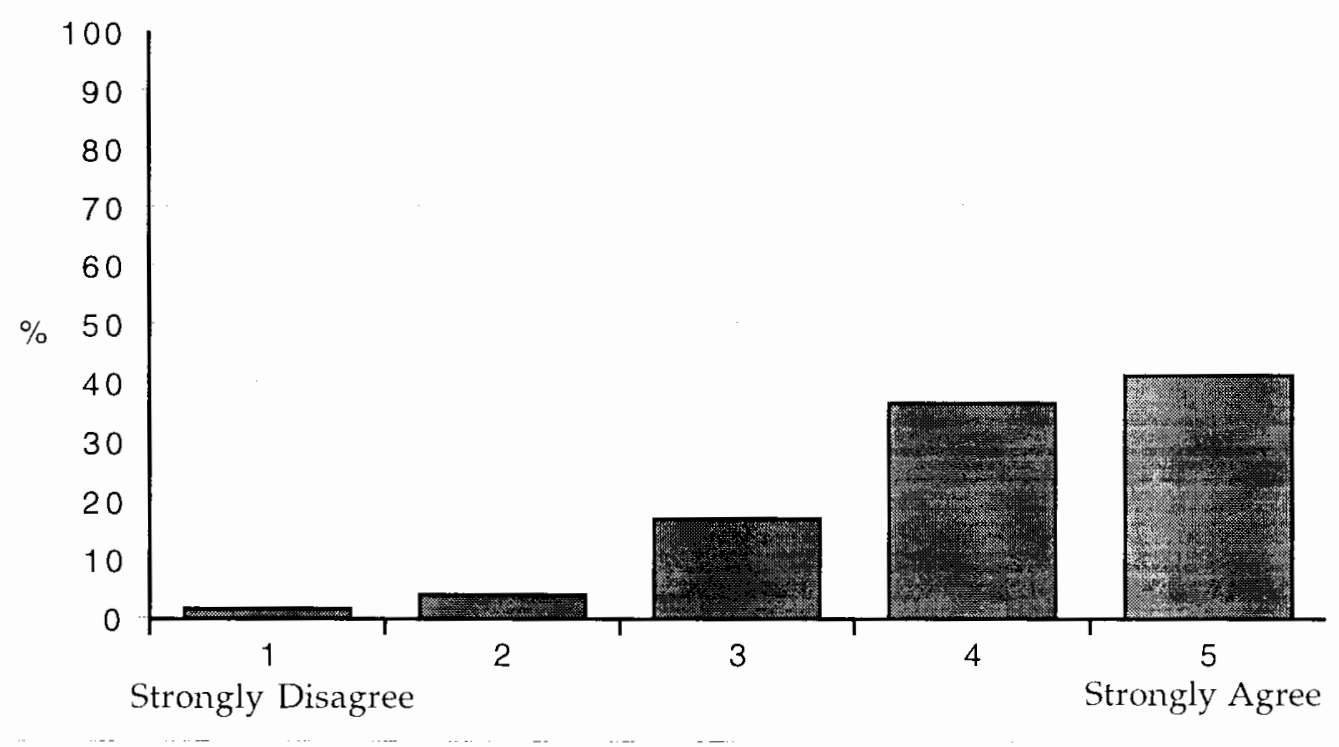

Figure 1. Responses to a statement, "I want teachers to correct my errors in speaking English." 
Respondents were given the option of explaining their reasons for answering each question in section B. Responses were categorized, and frequencies calculated. Table II depicts the summary of the reasons why the respondents agreed or disagreed with a statement, "I like teachers to correct my errors in speaking English."

\section{TABLE II}

\section{REASONS OF RESPONSES TO A STATEMENT,"I WANT MY TEACHERS TO CORRECT MY ERRORS IN SPEAKING ENGLISH."}

CATEGORY NAME EXAMPLES

Accuracy

*I want to speak correct English.

*I do not want to acquire innacurate English.

*Error correction improves my English/accuracy

Error Indicator * * usually don't realize my errors.

Future Benefit $\quad * \mid$ don't want to be in trouble because of erroneous English.

Duty Acceptability *Errors don't interfere with communication. *It is natural for English learners to make errors.

Confidence *I will lose confidence if I am corrected.

Others/No Reply
$2.4 \%$

FREQUENCY

$33.6 \%$

$8.4 \%$

$3.2 \%$

$3.4 \%$

$6.3 \%$

$42.8 \%$ 
Preferences for Overcorrection of Oral Errors

Participants were asked about their opinions about a statement,

"Teachers should correct all errors that learners make in speaking English." They were asked to rank one of the five choices by using a five-point scale ( $1=$ strongly disagree, $5=$ strongly agree). Nearly half of the respondents (278 responses, $47.4 \%$, represented by scores $1 \& 2$ ) disagreed with the opinion that all errors that learners make in speaking English should be corrected (Figure 2). One fifth of the respondents (120 responses, 20.4\%, represented by scores $4 \& 5$ ) agreed with overcorrection of oral errors. Figure 2 indicates a tendency toward disagreement with overcorrection of oral errors among the respondents. However, it is notable that the mode, i.e., the score with the greatest frequency, was 3 on a five-point scale. This means that one third of the respondents $(32.2 \%)$ neither agreed nor disagreed with overcorrection of errors in speaking English.

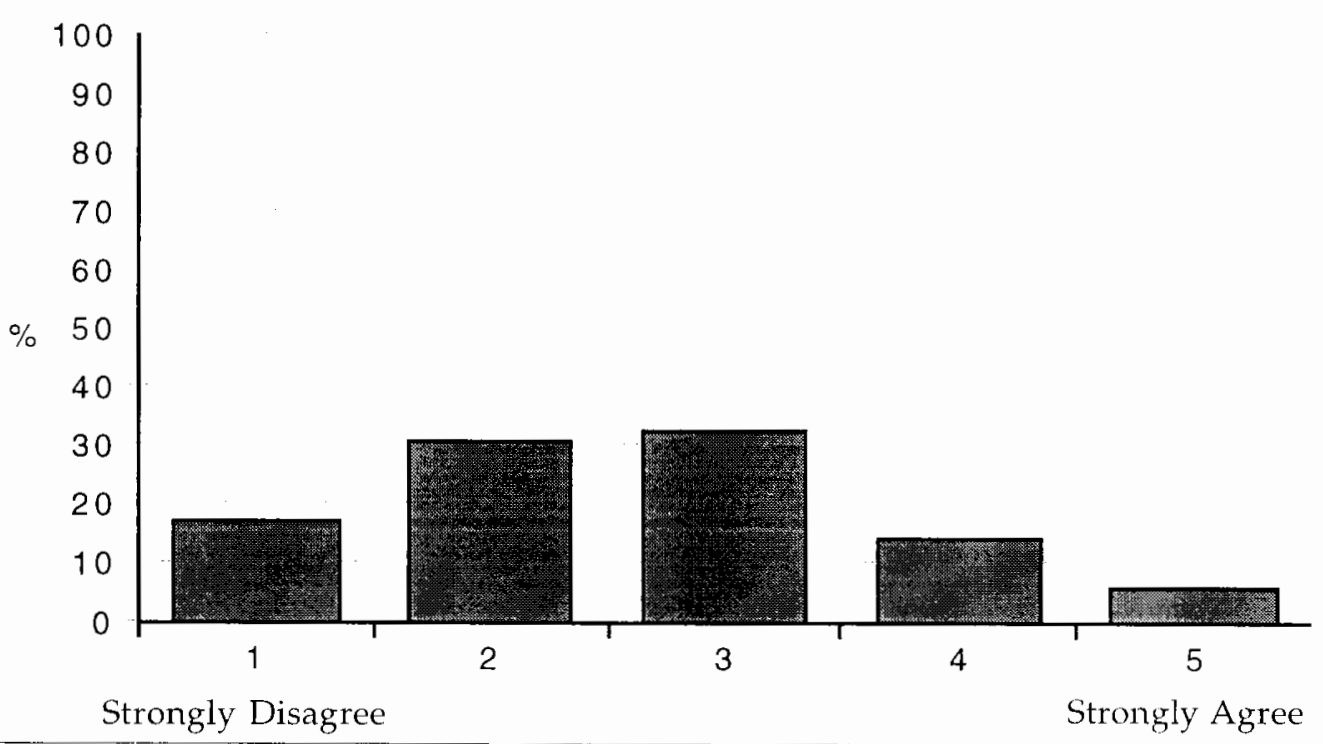

Figure 2. Responses to a statement, "Teachers should correct all errors that learners make in speaking English." 
Respondents were given the option of explaining their reasons why they agreed or disagreed with a statement, "Teachers should correct all errors that learners make in speaking English." Table III depicts the summary of the responses.

TABLE III
REASONS OF RESPONSES TO A STATEMENT,"TEACHERS SHOULD CORRECT ALL ERRORS THAT LEARNERS MAKE IN SPEAKING ENGLISH."

\begin{tabular}{|c|c|c|}
\hline CATEGORY NAME & EXAMPLES & FREQUENCY \\
\hline Accuracy & *I want to speak correct English. & $6.5 \%$ \\
\hline Discouraging & $\begin{array}{l}\text { * will lose confidence if all my errors } \\
\text { are corrected. } \\
\text { * I will lose the desire to continue to speak. }\end{array}$ & $17.6 \%$ \\
\hline Inteligibility & ${ }^{*}$ Communication succeeds with erroneous English. & $10.2 \%$ \\
\hline Serious Errors & *Only serious errors should be corrected. & $9.0 \%$ \\
\hline Impractical & $\begin{array}{l}\text { * It is impossible to correct all errors in large } \\
\text { classes. }\end{array}$ & $4.8 \%$ \\
\hline Interruption & *Overcorrection interrupts communication. & $3.6 \%$ \\
\hline Criteria & *There is no way to judge correctness of English. & $2.7 \%$ \\
\hline Others/No Reply & & $45.6 \%$ \\
\hline
\end{tabular}




\section{Preferences for Selective Error Correction}

Participants were asked about their opinions about a statement, "Teachers should correct only the errors that interfere with communication." The rating for how respondents agreed or disagreed with the statement was measured on a five-point scale (1=strongly disagree, $5=$ strongly agree). Forty percent of the respondents (represented by scores 4 \& 5) agreed with the opinion that teachers should employ selective error correction, while $32.7 \%$ (represented by scores $1 \& 2$ ) disagreed with it (Figure 3). The most frequent score was 3 on the five-point scale, which means that $27.3 \%$ of the respondents neither agreed or disagreed with the idea that English learners' oral errors should be corrected only when they impede communication. Figure 3 shows a slight tendency toward agreement with the selective error correction among the respondents.

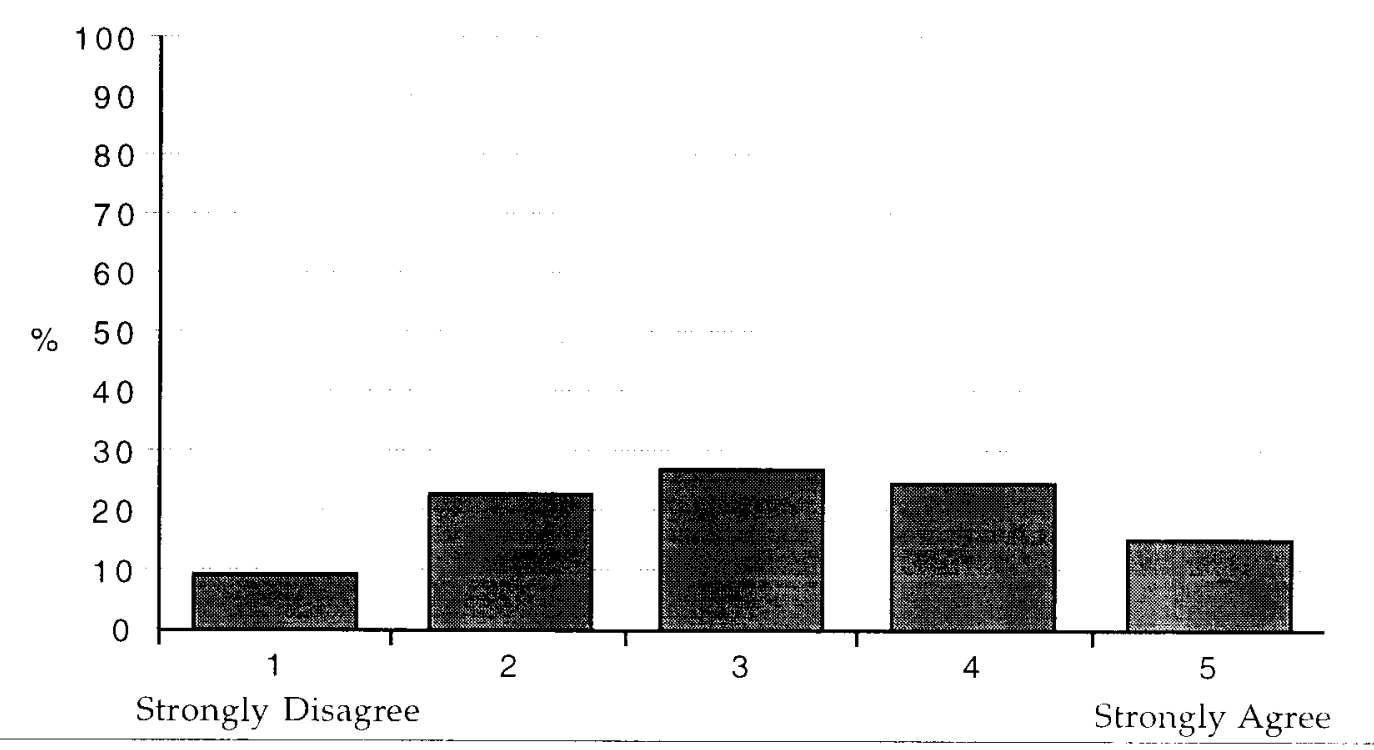

Figure 3. Responses to a statement, "Teachers should correct only the errors that interfere with communication." 
Respondents were given the option of explaining their reasons why they agreed or disagreed with a statement,"Teachers should correct only the errors that they interfere with communication." Table IV depicts the summary of the responses.

\section{TABLE IV}

REASONS OF RESPONSES TO A STATEMENT, “TEACHERS SHOULD CORRECT ONLY THE ERRORS THAT INTERFERE WITH COMMUNICATION."

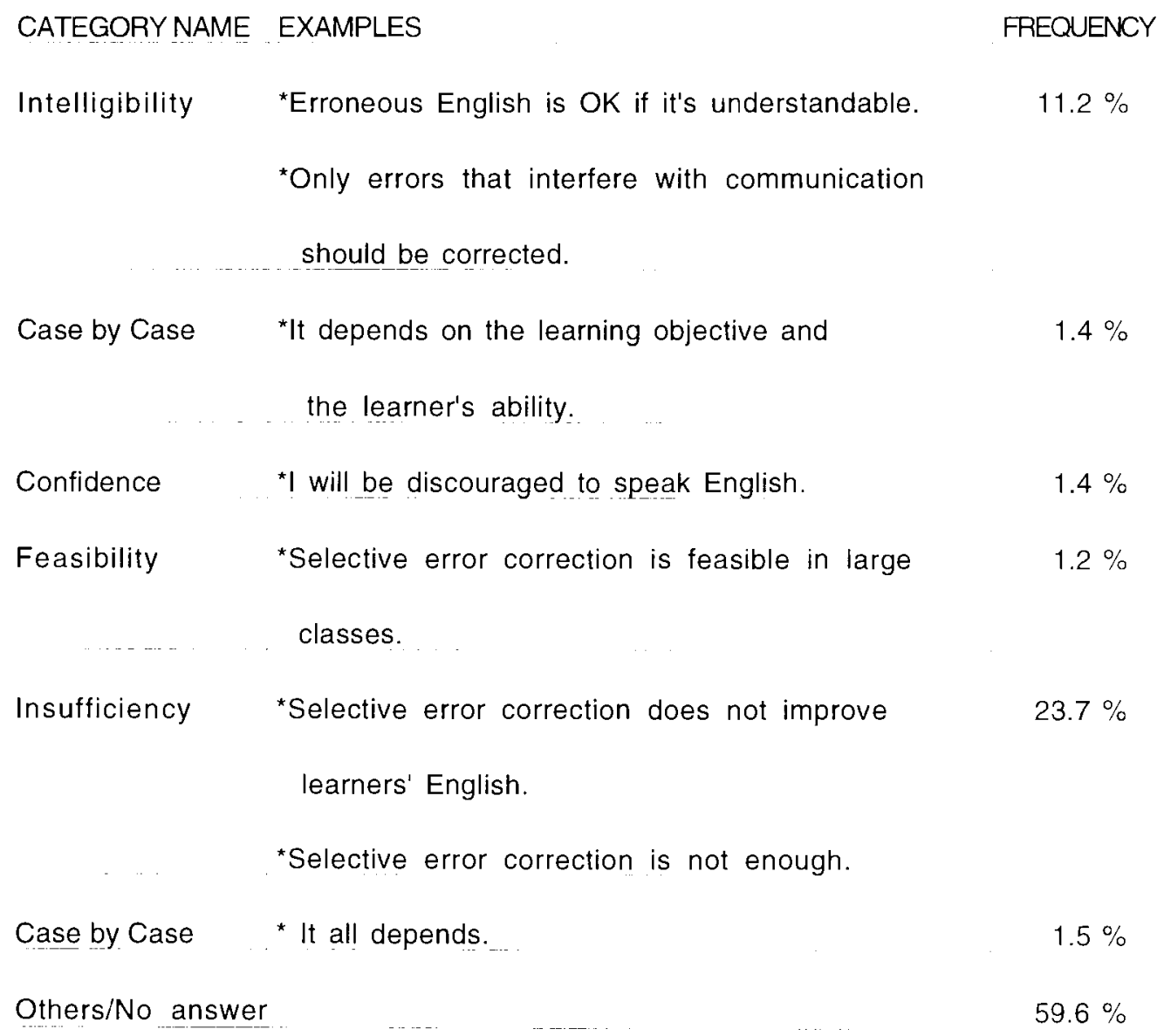




\section{Peer Correction}

Participants were asked if they agreed or disagreed with a statement, "I want my classmates to correct my oral errors in group work." They were asked to rank one of the five choices by using a five-point scale ( $1=$ strongly disagree, $5=$ strongly agree). Approximately half of the respondents $(50.7 \%$, represented by scores $4 \& 5$ ) agreed with the idea of peer correction, and nearly one fifth $(18.5 \%$, represented by scores $1 \& 2)$ disagreed with it (Figure 4). Nearly one third (30.8\%) of the respondents expressed neither agreement nor disagreement with the statement. Figure 4 shows a tendency toward agreement with peer correction among the respondents.

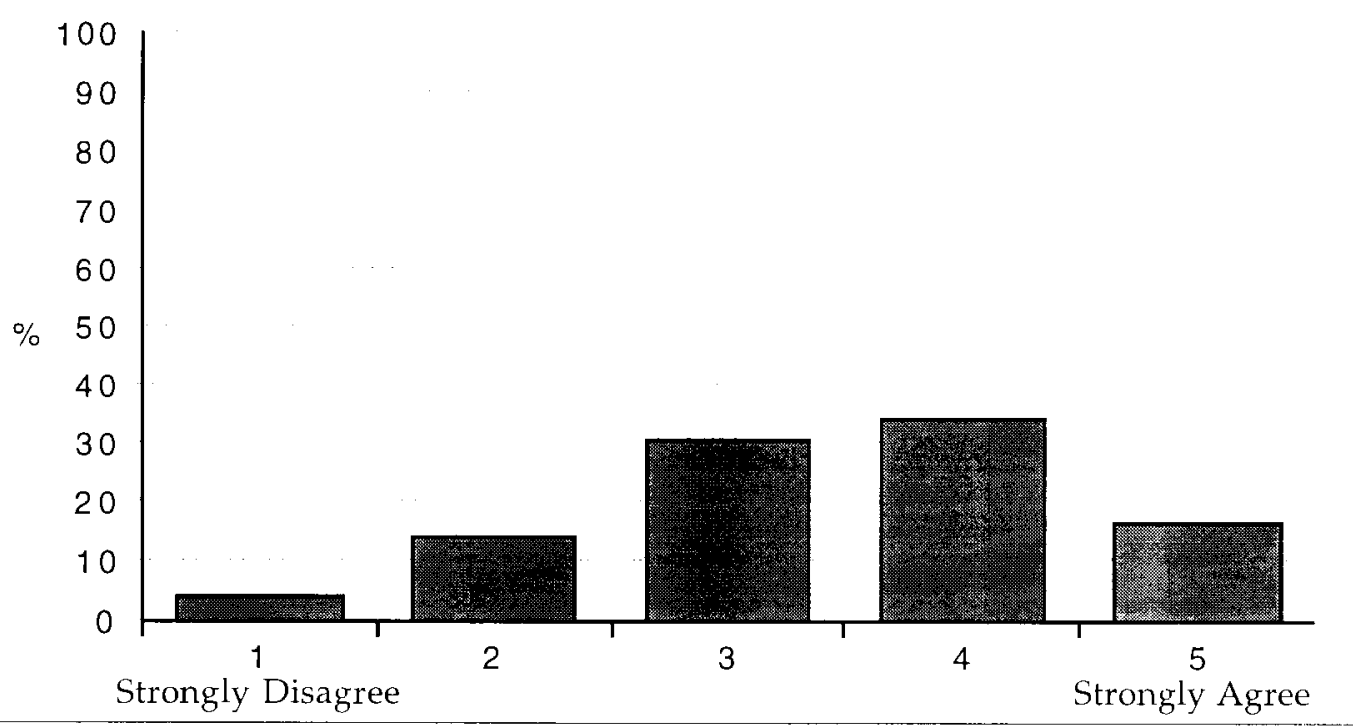

Figure 4. Responses to a statement, "I want my classmates to correct my oral errors in group work." 
Respondents were given the option of explaining their reasons why they agreed or disagreed with a statement, "I want my classmates to correct my oral errors in group work." Table V depicts the summary of the responses.

\section{TABLE V}

REASONS OF RESPONSES TO A STATEMENT, "I WANT MY CLASSMATES TO CORRECT MY ORAL ERRORS IN GROUP WORK."

\begin{tabular}{|c|c|c|}
\hline CATEGORY NAME & EXAMPLES & FREQUENCY \\
\hline Beneficial & $\begin{array}{l}\text { *It is beneficial to have my errors corrected } \\
\text { by my classmates. } \\
\text { "Both the one who corrects and the one who is } \\
\text { corrected benefit. }\end{array}$ & $15.0 \%$ \\
\hline Acceptability & $\begin{array}{l}\text { * feel much more comfortable being corrected } \\
\text { by my classmates than my teachers. }\end{array}$ & $3.6 \%$ \\
\hline Serious Errors & * want to have only serious errors corrected. & $2.1 \%$ \\
\hline Error Indicator & * usually don't realize my errors. & $1.0 \%$ \\
\hline Incapability & $\begin{array}{l}\text { * don't think my classmates are always right. } \\
\text { *I don't think my classmates' English is reliable. }\end{array}$ & $7.5 \%$ \\
\hline Inteligibility & $\begin{array}{l}\text { *Erroneous English is OK as long as it's } \\
\text { understood. }\end{array}$ & $4.4 \%$ \\
\hline Discomfort & $\begin{array}{l}\text { * feel uncomfortable about being corrected } \\
\text { by my classmates. }\end{array}$ & $2.2 \%$ \\
\hline Discouraging & * I wouldn't feel like speaking English. & $1.0 \%$ \\
\hline Others/No answer & & $63.2 \%$ \\
\hline
\end{tabular}


Relationship Between Attitudes and Levels of Proficiency

An analysis of attitudes toward error correction for levels of proficiency was conducted to determine if differences existed among the three groups of subjects on different levels of proficiency: Elementary, Intermediate, and Advanced. The Kruskal-Wallis Test revealed no significant differences among the three groups of the subjects regarding attitudes toward views about correction of oral errors at the $p=0.05$ level. This indicates that there was considerable agreement on the preferences for error correction among the subjects on different levels of proficiency in speaking English. This is an interesting finding, and will be further discussed in the next chapter.

\section{PART THREE: PREFERENCES FOR ERROR CORRECTION ON DIFFERENT ASPECTS OF THE LANGUAGE}

This part presents the results of the survey responses to the questions in Section $C$, which examined the general preferences for classroom oral error correction in different aspects of the language, i.e., grammar, vocabulary, etc. The findings are presented in the order of preference.

\section{Errors Regarding Pragmatics}

Participants were asked how often they wanted to have their errors regarding pragmatics corrected. Pragmatic errors were discussed in detail in Chapter III, therefore will not be reiterated again here. In the questionnaire "pragmatics"was presented as inappropriate expressions (e.g., When 
offering a drink: "Would you like some coffee"? is more appropriate than "Do you want to drink coffee"?) They were asked to rank one of the five choices by using a five-point scale ( $1=$ never, $5=$ always $)$. The strong preference for correction of pragmatics errors was observed with the median score 5. The median is "the value of a set of scores which has the same number of observations above and below it when the observations are ranked from highest to lowest" (Nunan, 1993, p.231). Of the 586 respondents, the majority, $89.9 \%$ (represented by scores $4 \& 5$ ), wanted to have their oral errors regarding pragmatics corrected. It is interesting to note that $62 \%$ of the respondents wanted to have their errors relating to pragmatics always $(=5)$ corrected (Figure 5 ).

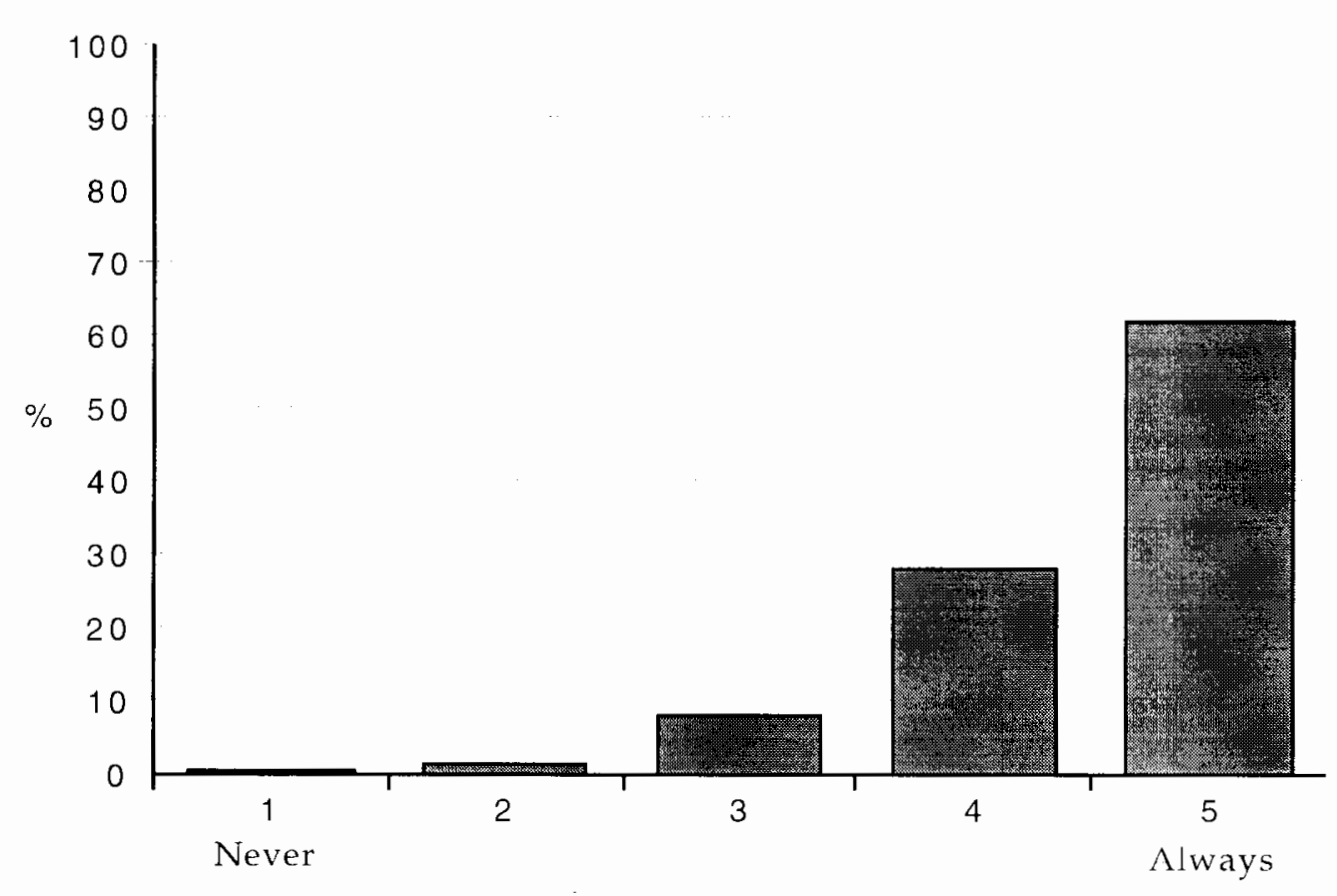

Figure 5. Preferences for correction of errors regarding pragmatics. 
Phonological Errors

Respondents (586) were asked how often they wanted to have their phonological errors corrected. The majority $(84.7 \%$, represented by scores 4 $\& 5$ ) expressed that they wanted to have their errors corrected (Figure 6). Nearly half $(47.1 \%)$ of the respondents scored 5 (5=always), and $38.6 \%$ scored 4 . The median was 4 on a five-point scale.

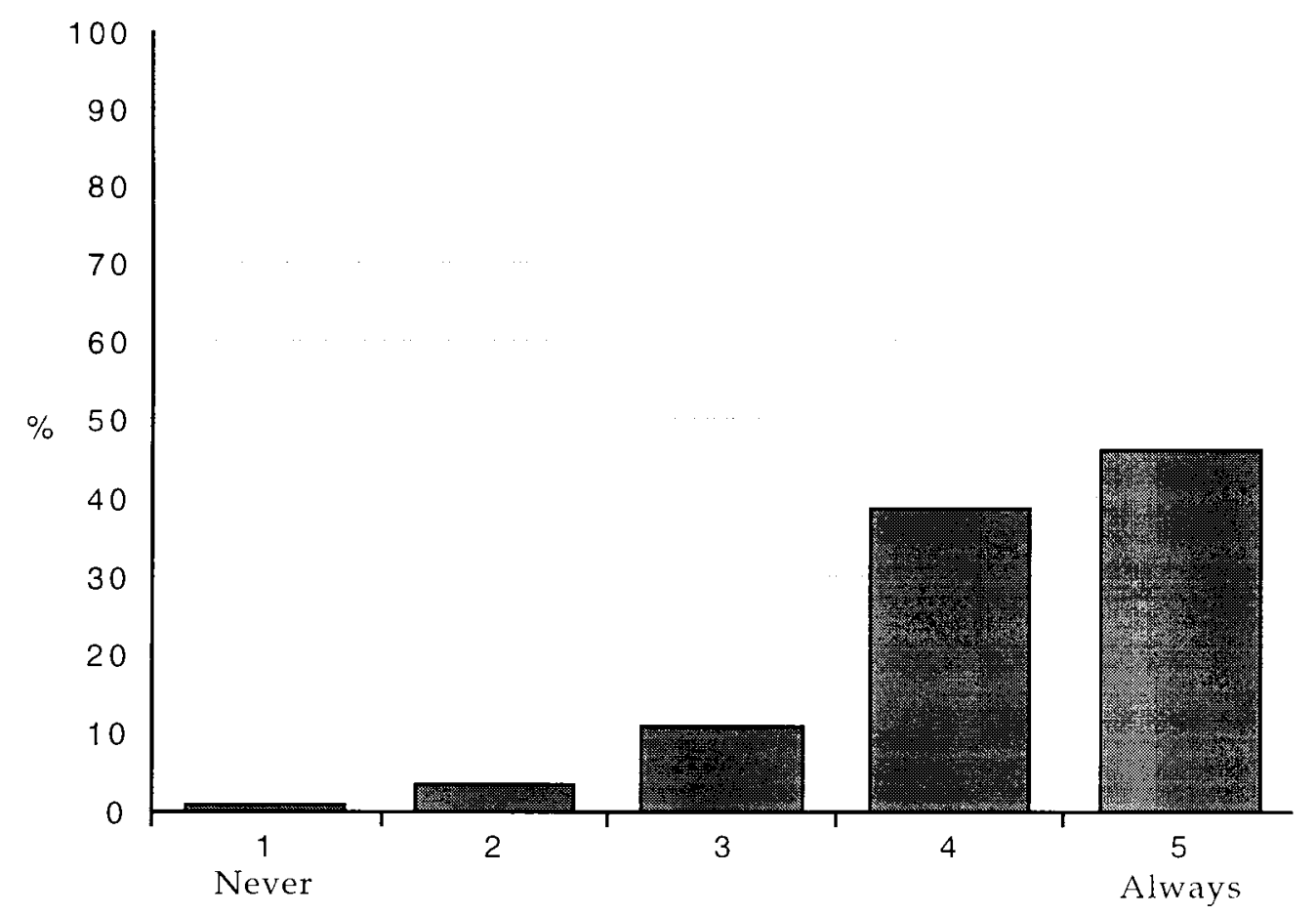

Figure 6. Preferences for correction of phonological errors. 
Vocabulary Errors

Respondents (586) were asked their preferences for correction of errors on vocabulary. The majority $(77.3 \%$, represented by scores $4 \& 5)$ reported that they wanted to have their vocabulary errors corrected (Figure 7). Nearly half ( $47.3 \%)$ scored 4 , and 30\% scored 5 (5=always). The median was 4 on a five-point scale.

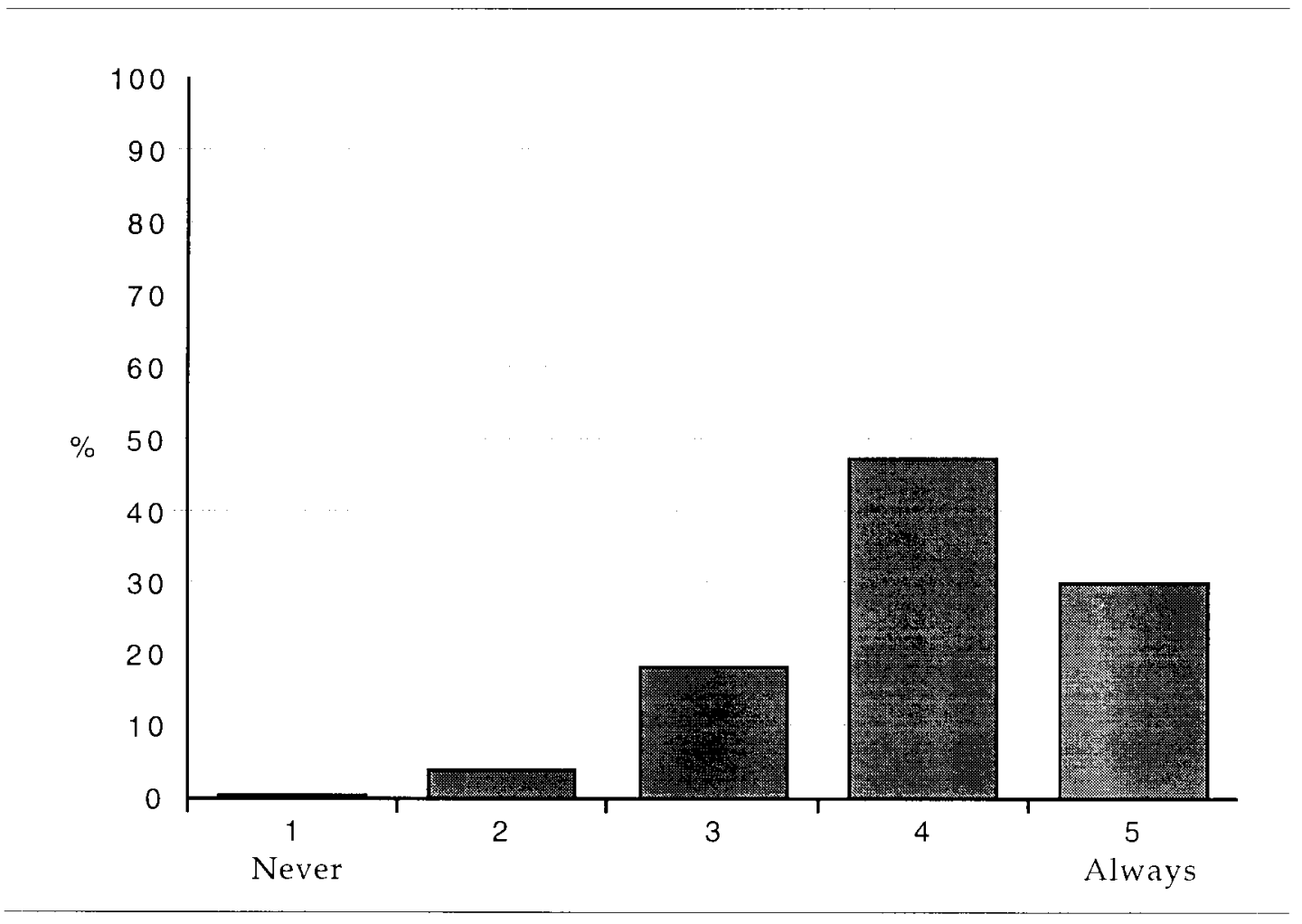

Figure 7. Preferences for correction of vocabulary errors. 
Grammatical Errors

Respondents (568) were asked how often they wanted to have their grammatical errors corrected. Approximately half of them $(52.2 \%$, represented by scores $4 \& 5$ ) expressed that they wanted to have their grammatical errors corrected (Figure 8 ). Nearly one third $(32.4 \%)$ scored 4 , and $19.8 \%$ scored 5 . Over one third of the respondents (35.8\%) had neutral attitudes toward correction of grammatical errors. The median was 4 .

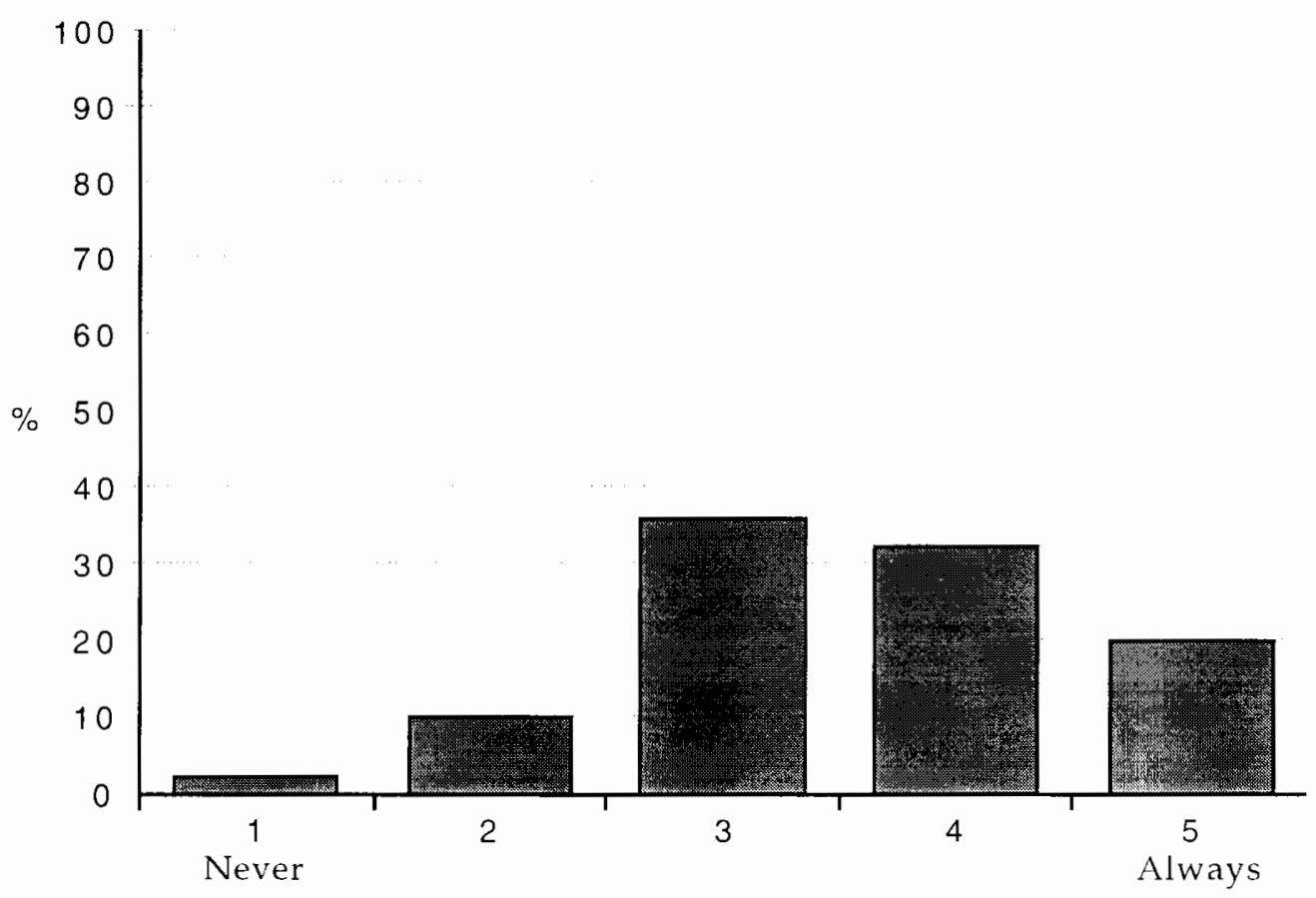

Figure 8. Preferences for correction of grammatical errors. 
Errors Regarding Discourse

Respondents (567) were asked how often they wanted to have their errors relating to discourse corrected. Discourse errors were discussed in detail in Chapter III, therefore will not be reiterated again here. In the questionnaire, "discourse" was presented as organization of discourse (e.g., how to negotiate or persuade). Half of them (50.3\%, represented by scores 4 \& 5) expressed that they wanted to have their errors regarding discourse corrected (Figure 9). Approximately one third of them (32.2\%) scored 4, and $18.1 \%$ scored 5 (5=always). Over one third of the respondents $(34.2 \%)$ had neutral attitudes toward correction of errors regarding discourse. The median was 4 .

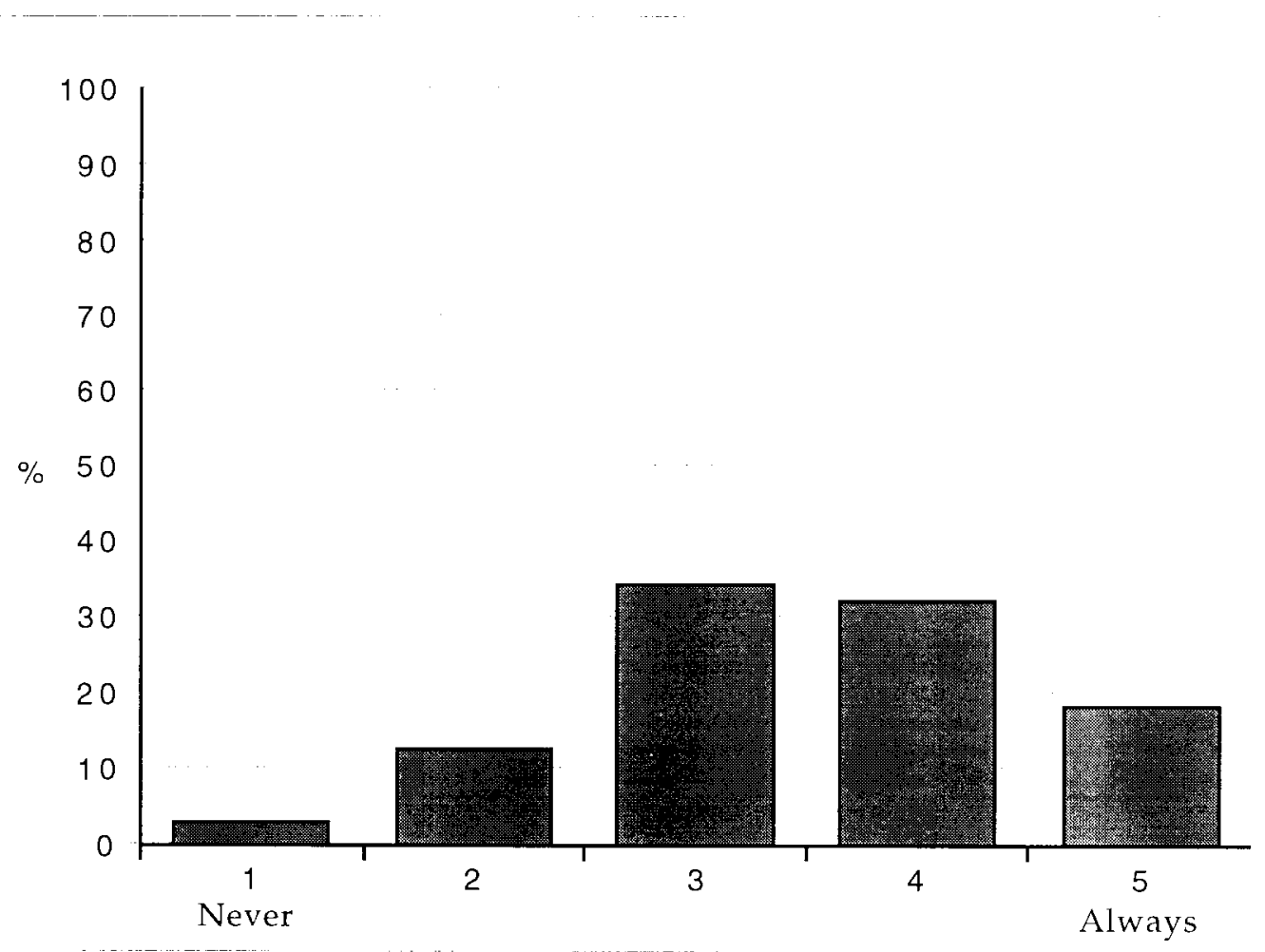

Figure 9. Preferences for correction of errors regarding discourse. 
Relationship between Preferences for Error Correction on Different Aspects of the Language and Proficiency Levels

The three groups of the respondents (Elementary, Intermediate, and Advanced students) were compared to examine if the relationship between preferences for error correction on different aspects of the language and levels of proficiency revealed any significant differences. The KruskalWallis Test revealed no significant differences among the three groups in preference for correction of errors relating to grammar, phonology, pragmatics, and vocabulary. However, significant differences were revealed among the groups for attitudes toward error correction of errors regarding discourse with the p-value of 0.0225 . The median of each group was 3 on the five-point scale for Elementary students, and 4 for Intermediate and Advanced students. The proportion of Advanced students who chose 5 was larger than those of the Elementary and Intermediate students.

\section{PART FOUR: PREFERENCES FOR TYPES OF ERROR CORRECTION}

This part presents the results of the survey responses to the questions in Section D, which investigated the general preferences for particular types of classroom correction in speaking. Findings are presented in the order of preference.

\section{Preferred Types of Correction Method}

Participants were asked to rate various methods of error correction provided by teachers as feedback to students' errors in speaking English. 
Examples of errors were presented in the questionnaire as follows:

Example of grammatical error:

Teacher: "Where did you go yesterday"?

Student: "I go to the park."

Example of pronunciation error:

Teacher: "What kind of flowers do you like best"?

Student: "I like loses best."

The rating for their opinions about each method was measured on a five-point Likert scale ( $1=$ not good, $5=$ very good). The majority of the participants favored the error correction methods listed in Table VI. The median in a grouped frequency distribution for each of these methods was 4 on the 5-point scale. These methods are listed in the order of preference based on the percentage of the respondents who scored 4 and 5 (5=very good). Percentages ranged from $60 \%$ to $70 \%$.

The most preferred type of correction for grammatical errors was when the teacher gives the student a hint which might enable the student notice the error and self-correct: "Where did you say you went yesterday"? Seventy percent scored 4 and 5 ( $5=$ very good) to this method.

The second most favored correction method for grammatical errors was the one in which the teacher explains why the response is incorrect: "Go is the present tense. You need the past tense here." Sixty-four point two percent of the participants (represented by scores 4 \& 5) favored this method. This method received 5 ( $5=$ very good) from the largest proportion of respondents $(35.1 \%)$ of all the methods listed in the questionnaire.

Another popular method for grammatical errors was the one in 
which the teacher points out the error, and provides the correct response: "Go is wrong. You should say went." This correction method was favored by $64.2 \%$ (represented by scores $4 \& 5$ ).

One last preferred method for grammatical errors was when the teacher presents the correct response or part of the response: "I went to the park" or "Went." This method was favored by 60.6\% (represented by scores $4 \& 5)$.

Regarding methods for pronunciation errors, respondents favored a technique in which the teacher gives the student a hint that might enable the student to notice the error and self-correct: "What color of roses do you like"? This correction method was favored by $64.4 \%$ (represented by scores $4 \& 5)$.

The second most preferred method for pronunciation errors was a technique in which the teacher points out the error, and provides the correct response: "Loses is wrong. You should say roses." This correction method was favored by $64.1 \%$ (represented by scores $4 \& 5$ ).

Another popular method for pronunciation errors was a type in which the teacher presents the correct response or part of the response: "I like roses best" or "Roses." This correction method was favored by $63.0 \%$ (represented by $4 \& 5$ ).

One last method which was preferred by the majority of the respondents was a technique in which the teacher explains why the response is incorrect: (Using a picture of a mouth) "When you pronounce $\underline{r}$ for roses, your tongue should not touch the roof of the mouth. It should..." This correction method was favored by $62.9 \%$ (represented by scores $4 \& 5$ ). 
The second largest proportion of the respondents $(34.5 \%)$ scored 5 to this method of all the methods listed in the questionnaire.

\section{TABLE VI}

\section{PREFERRED METHODS OF ERROR CORRECTION:PERCENTAGES OF RESPONSES}

CORRECTION METHOD

EXAMPLE

"T gives $\mathrm{S}$ a hint which might " Where did you say you went enable $S$ to notice the error

$G$ and self-correct.

$R$ *T explains why the response

A is incorrect.

$M$

$M{ }^{*} T$ points out the error, and

A provides correct response.

R

*T presents the correct response or part of the response.

${ }^{*} T$ gives $S$ a hint which might

$P$ enable $S$ to notice the error

$\mathrm{R}$ and self-correct.

$O{ }^{*} T$ points out the error, and

$\mathrm{N}$ provides correct response.

$\mathrm{U}$

C ${ }^{*} T$ presents the correct

1 response or part of the

A response.

$T$ * $T$ explains why the response

1 incorrect.

$\mathrm{O}$

$\mathrm{N}$
"Go is wrong. You should say

yesterday"?

"Go is the present tense. You $29.1 \% \quad 35.1 \% \quad 64.2 \%$ need the past tense here."

went."

"I went to the park." or

"Went." .

"What color of roses do you like"?

"Loses is wrong. You should say roses."

"I like roses best." or "Roses."

(Using a picture of a mouth) "When you pronounce $r$ for roses, your tongue should not touch the roof of the mouth. It should..."
FREQUENCY OF RE CEIVING

$$
4 \quad 54 \& 5
$$

$36.3 \% 33.7 \% 70.0 \%$

$32.3 \% 31.9 \% 64.2 \%$ $34.0 \% 26.6 \% 60.6 \%$ $33.6 \% 30.8 \% 64.4 \%$ $30.9 \% 33.2 \% 64.1 \%$ $34.8 \% 28.2 \% 63.0 \%$

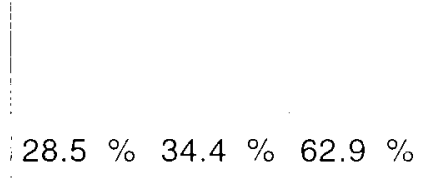

:


Methods Neither Favored Nor Disliked

Several correction methods were neither favored nor unfavored by the participants of this study (Table VII). The largest proportion of the participants chose 3 on the five-point scale, and the rest were divided into either favor or dislike. The median score for each of these methods was 3.

Two of these neutral methods showed slight tendency toward favor, in that the proportion of the respondents who scored 4 and 5 (=very good) was larger than the proportion of those who scored 1 (=not good) and 2. One of them is a method in which the teacher repeats the student's utterance up to the error, and waits for self-correction: "I..." This method received 4 and 5 from $40.7 \%$, and 1 and 2 from $27.8 \%$. Another is a method for pronunciation errors in which the teacher repeats the student's utterance up to the error, and waits for self-correction: "I like..." This method received 4 and 5 from $36.4 \%$, and 1 and 2 from $33.7 \%$.

Among the correction methods that were neither preferred nor disliked by the respondents, five of the methods had slight tendency toward being disliked. The proportions of the respondents who disliked these methods were larger than the proportions of the respondents who favored them. One of these techniques is a correction method for grammatical and pronunciation errors in which the teacher indicates that an error occurred with nonverbal behavior. This method received 1 and 2 from $41.0 \%$, and 4 and 5 from $31.6 \%$. Another is a correction method for grammatical errors in which the teacher asks the student to repeat the utterance: "Please say that again." This method received 1 and 2 from $40.8 \%$, and 4 and 5 from $29.7 \%$. A third technique is a correction method 
for pronunciation errors in which the teacher asks the student to repeat the utterance: "Please say that again." This method received 1 and 2 from 39.5 $\%$, and 4 and 5 from $33.3 \%$. The method for pronunciation errors in which the teacher indicates the error ("No. Not loses.") received 1 and 2 from $36.1 \%$, and 4 and 5 from $34.4 \%$. The method for grammatical errors in which the teacher indicates the error ("No. Not go.") received 1 and 2 from $35.7 \%$, and 4 and 5 from $34.6 \%$.

\section{TABLE VII}

\section{METHODS NEITHER PREFERRED NOR DISLIKED: PERCENTAGES OF RESPONSES}

\begin{tabular}{|c|c|c|c|c|c|}
\hline & \multirow{3}{*}{ CORRECTION METHOD } & \multirow{3}{*}{ EXAMPLE } & \multicolumn{3}{|c|}{ FREQUENCY OF RECIEVING } \\
\hline & & & $1=$ not good & & $5=$ very good \\
\hline & & & $1 \& 2$ & 3 & $4 \& 5$ \\
\hline & $\begin{array}{l}{ }^{*} T \text { repeats S's utterance } \\
\text { up to the error, and } \\
\text { waits for self-correction. }\end{array}$ & $" 1 \ldots "$ & $27.8 \%$ & $31.5 \%$ & $40.7 \%$ \\
\hline$A$ & $\begin{array}{l}{ }^{*} T \text { indicates that an error } \\
\text { occured with nonverbal } \\
\text { behavior. }\end{array}$ & & $41.0 \%$ & $27.4 \%$ & $31.6 \%$ \\
\hline A & $\begin{array}{l}{ }^{*} T \text { asks the } S \text { to repeat the } \\
\text { utterance. }\end{array}$ & "Please say that again." & $40.8 \%$ & $29.5 \%$ & $29.7 \%$ \\
\hline & ${ }^{*} T$ indicates the error. & "No. Not go." & $35.7 \%$ & $29.7 \%$ & $34.6 \%$ \\
\hline$P$ & $\begin{array}{l}{ }^{*} T \text { repeats S's utterance } \\
\text { up to the error, and } \\
\text { waits for self-correction. }\end{array}$ & "I like..." & $33.7 \%$ & $29.9 \%$ & $36.4 \%$ \\
\hline $\mathrm{N}$ & $\begin{array}{l}{ }^{*} T \text { indicates that an error } \\
\text { occured with nonverbal } \\
\text { behavior. }\end{array}$ & & $41.0 \%$ & $27.4 \%$ & $31.6 \%$ \\
\hline 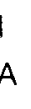 & $\begin{array}{l}{ }^{*} T \text { asks the } S \text { to repeat the } \\
\text { utterance. }\end{array}$ & "Please say that again." & $39.5 \%$ & $27.2 \%$ & $33.3 \%$ \\
\hline 1 & ${ }^{*} T$ indicates the error. & "No. Not loses." & $36.1 \%$ & $29.5 \%$ & $34.4 \%$ \\
\hline
\end{tabular}


Disliked Method

The majority of the participants of this study disliked four of the methods listed in the questionnaire (Table VIII).

The least preferred method of correction for both grammatical and pronunciation errors was a technique in which the teacher ignores students' errors. This method received 1 and 2 from $88.8 \%$. It is interesting to note that the largest proportion of the respondents $(60.6 \%)$ scored 1 (=not good). The median score for this method was 1 .

The second least preferred method was a technique in which the teacher repeats the original question. This method for pronunciation errors received 1 and 2 from $65.8 \%$. The same method for grammatical errors received 1 and 2 from $61.8 \%$. The median for this method for both grammatical and pronunciation errors was 2 .

\section{TABLE VIII}

UNFAVORED METHODS: PERCENTAGES OF RESPONSES

\begin{tabular}{|c|c|c|c|c|c|}
\hline & \multirow{2}{*}{ CORRECTION METHOD } & \multirow[t]{2}{*}{ EXAMPLE } & \multicolumn{3}{|c|}{ FREQUENCY OF RECEIVING } \\
\hline & & & 1 & 2 & $1 \& 2$ \\
\hline $\begin{array}{l}G \\
R\end{array}$ & ${ }^{*} T$ ignores S's errors. & & $60.6 \%$ & $28.2 \%$ & $88.8 \%$ \\
\hline $\begin{array}{l}A \\
M \\
M\end{array}$ & $\begin{array}{l}{ }^{*} T \text { repeats the original } \\
\text { question. }\end{array}$ & $\begin{array}{c}\text { "Where did you go } \\
\text { yesterday"? }\end{array}$ & $28.3 \%$ & $33.5 \%$ & $61.8 \%$ \\
\hline$P$ & ${ }^{*} T$ ignores S's errors. & & $60.6 \%$ & $28.2 \%$ & $88.8 \%$ \\
\hline $\begin{array}{l}R \\
O \\
N \\
U\end{array}$ & $\begin{array}{l}{ }^{*} T \text { repeats the original } \\
\text { question. }\end{array}$ & $\begin{array}{l}\text { "What kind of flowers do } \\
\text { you like best"? }\end{array}$ & $31.9 \%$ & $33.9 \%$ & $65.8 \%$ \\
\hline
\end{tabular}


Relationship between Preferences for Error Correction Method and Proficiency Levels

The three groups of the respondents (Elementary, Intermediate, and Advanced) were compared to examine if the relationship between preferences for error correction methods and levels of proficiency revealed any significant differences.

The Kruskal-Wallis Test was employed to analyze differences among the three groups in their preferences for correction methods. A significant difference was observed for a method for pronunciation errors with a $\mathrm{p}$ value of $0.007(p<0.05)$. This method was the one in which the teacher presents the correct response or part of the response. The median was 4. A larger proportion of the respondents in the group of Intermediate and Advanced students scored 5 (5=very good) than those in the group of Elementary. This indicates that Intermediate and Advanced students had more positive attitude than Elementary students toward the method in which the teacher presents the full or partial correct response.

There was also a significant difference among the groups regarding preference for the same type of technique for grammatical errors, with a $\mathrm{p}$ value of $0.321(\mathrm{p}<0.05)$. The Intermediate and Advanced students favored the method for grammatical errors in which the teacher presents the full or correct response more than Elementary students.

Results from The Kruskal-Wallis Test indicated that a difference among proficiency levels was not observed for most correction methods except for the ones mentioned above. This is an important finding, and will be discussed further in the next chapter. 
PART FIVE: DIFFERENCES IN

PREFERENCE BETWEEN SUBGROUPS

\section{Differences Between Gender}

An analysis of preferences for error correction between males and females was conducted to determine if any differences existed between gender. Kraskul-Wallis Test results revealed that there was a significant difference between gender for preference of a correction method with a pvalue of 0.0033 . It was the method in which the teacher ignores the student's errors. Results showed that respondents' overall attitudes toward this method was strongly negative (The median was 1). However, the top $10 \%$ of the males gave 5 ( 5 =very good) to this method, while $10 \%$ of the females gave 4 on a five-point scale.

\section{Differences Among Academic Major Fields}

An analysis of preferences for error correction across major fields of study was conducted to examine if any differences existed between major fields. The major fields of all respondents were grouped into two categories: English Majors, which consisted of the students majoring in English literature and English as a second language; and Non-English Majors, which consisted of the students majoring in other fields of study.

Results from the Kruskal-Wallis Test indicated that there were no differences between the two groups in preference for teacher correction, selective error correction, and peer correction. However, a significant difference was observed between the groups in preference for overcorrection of errors, with a $\mathrm{p}$-value of $0.0308(\mathrm{p}<0.05)$. The median 
score of the overall responses was 3 . The median score of the responses of English-Majors was 3, while that of Non-English Majors was 2.

The Kruskal-Wallis Test also revealed significant differences between English Majors and Non-English Majors in preference for correction of phonological and discourse errors with a p-value of 0.0026 and 0.0005 , respectively $(\mathrm{p}<0.05)$. For phonological errors, the median score of the responses of English-Majors was 5 (5=Always), while that of NonEnglish Majors was 4 on a five-point scale. For errors relating to discourse, the median score of the responses of English-Majors was 4, while that of Non-English Majors was 3. With regard to preference for correction of errors on grammar, vocabulary, and pragmatics, no significant differences between the groups were observed.

The Kruskal-Wallis Test also revealed that there were no differences between English Majors and Non-English Majors regarding their preferences for error correction methods.

Differences Between Students Who Wanted to Improve English and Those Who Did Not

Two groups of the students: those who wanted to improve their English and those who did not, were compared to determine if any attitudinal differences existed between these groups. The Kruskal-Wallis Test revealed significant differences between the two groups regarding their preferences for correction of errors relating to discourse, with a pvalue of $0.0151(\mathrm{p}<0.05)$. The median scores of the responses of the students who wanted to improve their English and those who did not were 
respectively 4 and 3 on a five-point scale. The median score of the overall responses was 4 . This was the only observed difference between the two groups.

Differences According to Experience and Length of Living in an Englishspeaking Country

Two groups of the students: those who had lived in an Englishspeaking country for one month or more and those who had lived less than one month or not at all, were compared regarding differences in preference for error correction. The Kruskal-Wallis Test revealed a significant difference between the two groups in preference for correction of errors relating to discourse, with a $\mathrm{p}$-value of $0.0105(\mathrm{p}<0.05)$. The median score of the responses of the students who had lived in an Englishspeaking country for one month or more was 4 . The median for those who had lived in an English-speaking country less than one month or not at all was 3. The median score of the overall responses was 4 . This was the only significant difference observed between the two groups.

\section{Differences According to Opportunity to Speak English Outside of Class}

The two groups of the students: those who had opportunities to speak English outside of class and those who did not have opportunities, were compared regarding preferences for error correction.

Results from The Kruskal-Wallis Test indicated that there was no significant difference between the two groups in preference for teacher correction, overcorrection of errors, selective correction, or peer-correction.

With regard to preference for correction of errors on different aspects 
of the language, the Kruskal-Wallis Test revealed a significant difference between the two groups in preference for correction of errors relating to discourse, with a p-value of $0.0208(\mathrm{p}<0.05)$. The median score of the responses of the students who had opportunities to speak English outside of class was 4 . The median for those who did not have opportunities to speak English outside of class was 3. The median score of the overall responses was 4 . This was the only significant difference between the two groups in preference for correction of errors on different aspects of the language.

The Kruskal-Wallis Test results indicated that there was no significant difference between the two groups in preference for methods of error correction except for one method. A significant difference between the groups was observed in preference for a method for pronunciation errors in which the teacher repeats the last word in the student's correct utterance and waits for self-correction $(\mathrm{p}=0.0141)$. The median scores of the responses of the students who had opportunities to speak English outside of the classroom and those who did not were respectively 4 and 3. The median score of the overall responses to this correction method was 3.

\section{SUMMARY}

The respondents had a strong positive agreement in regard to correction of oral errors by teachers. They showed a tendency toward agreement concerning peer correction, and a slight tendency toward agreement regarding selective error correction. Concerning overcorrection 
of errors, they showed a tendency toward disagreement. There was no significant difference among the different levels of English proficiency.

The respondents had positive attitudes toward the correction of all five types of errors listed in the questionnaire. Errors relating to pragmatics received the strongest preference. A significant difference among the three proficiency levels was observed in only preference for correction of errors in discourse.

The respondents preferred four methods of error correction: 1) the teacher gives the student a hint which might enable the student to notice the error and self-correct, 2) the teacher explains why the response is incorrect, 3) the teacher point out the error, and provides the correct response, and 4) the teacher presents the correct response or part of the response. The methods that the respondents did not prefer were: 1) the teacher ignores the student's errors and 2) the teacher repeats the original question asked of the student. A significant difference among the groups was observed in preference for only one error correction method: the teacher presents the correct response or part of the response. This was true for for both grammatical and phonological errors.

One of the findings from additional analysis was a significant difference in preference for correction of errors regarding discourse between various subgroups. The corresponding subgroups with differing preferences include: 1) English Major students and Non-English Major students, 2) students who wanted to improve English and those who did not, 3) students who had lived in an English-speaking country for one month or more and those who had lived less than one month or not at all, 
4) students who had opportunities to speak English outside of class and those who did not have opportunities. 


\section{CHAPTER V}

\section{DISCUSSION}

\section{INTRODUCTION}

This chapter discusses findings from the research questionnaire, limitations of the study, implications of the analysis of data, and recommendation for the further research.

\section{DISCUSSION OF RESEARCH QUESTIONS AND HYPOTHESES}

Research Question 1: What are the general preferences for classroom error correction in speaking among university students in Japan?

Hypothesis 1: University students of English in Japan have positive attitudes toward teacher correction and negative attitudes toward overcorrection, selective error correction, and peer correction.

Regarding teacher correction of oral errors, the majority of the students $(77.0 \%)$ responded positively. Therefore, hypothesis 1 was supported in that Japanese students of English in Japan have positive attitudes toward teacher correction of oral errors. This result is consistent with those of Cathcart and Olsen's (1976), Chenoweth et al.'s (1983), and Oladejo's (1993). The most frequent reason for desiring teacher correction 
given by the students was the belief that error correction would improve their accuracy in oral English.

Concerning overcorrection of errors, only a tendency toward disagreement was observed. Nearly half of the students $(47.4 \%)$ disagreed with overcorrection, one fifth $(20.4 \%)$ agreed with overcorrection, and one third $(32.2 \%)$ neither agreed nor disagreed with overcorrection. Thus, hypothesis 1 was not supported in that the university students of English in Japan have negative attitudes toward overcorrection of errors. The finding does not support the consensus that teachers should not correct all errors that learners make in speaking English (Hendrickson, 1978). It is interesting to note that over half of the students did not disagree with overcorrection. Considering the large sizes of classes in Japan, it is impractical for the teacher to correct all errors that the students make. Thus, one could expect that the majority of the students in Japanese universities disagree with overcorrection of oral errors.

In regard to selective error correction, a slight tendency toward agreement was observed. One fifth of the students (40.0\%) agreed with selective error correction and $32.7 \%$ disagreed with selective error correction. Nearly one third (27.3\%) neither agreed nor disagreed with selective error correction. Therefore, hypothesis 1 was not supported in that the university students of English in Japan have negative attitudes toward selective error correction. The researcher hypothesized that the majority of the university students of English in Japan believe that selective error correction is insufficient in order to improve their English. This assumption was supported by the comments made by some of the 
students in this study. Some $(23.7 \%)$ commented that selective error correction is not enough to improve their English. Others commented that they wanted teachers not to limit error correction to only those that interfere with communication. However, the result indicates that the students have a slightly positive attitudes toward selective error correction.

Regarding peer correction, the students showed a tendency toward agreement. Half of them $(50.7 \%)$ wanted their classmates to correct their oral errors during group/pair work. Nearly one fifth $(18.5 \%)$ disagreed with peer correction. Nearly one third $(30.8 \%)$ neither agreed nor disagreed with peer correction. This finding did not support Hypothesis 1 in that Japanese students of English in Japan have negative attitudes toward peer correction. The researcher constructed this hypothesis based on the assumption that the students do not expect to have their oral errors corrected because peer correction violates "ingroup harmony" (Gudykunst \& Nishida, 1993, p.173) - an important cultural value in Japan. Within a group, Japanese people try to avoid expressing their opinions which may differ or counter those of other group members and destroy the harmonious relationship with the members (Nakanishi, 1986). This was demonstrated in a study by Cole (1989) in which Japanese people perceived criticisms as "face threats" (cited in Gudykunst \& Nishida, 1993). The researcher postulated that the students in the present study might perceive criticisms from peers also as "face threats," with potential to destroy ingroup harmony. Contrary to the researcher's assumption, only a few students (13 responses, $2.2 \%$ ) expressed that they felt uncomfortable with peer correction. They commented that being corrected by their peers made 
them feel embarrassed or upset, or hurt their pride. Some commented that they felt reluctant to correct errors made by peers.

Research Question 2: Do the general preferences for classroom error correction in speaking differ according to students' level of proficiency in the language?

Hypothesis 2: The general preferences for classroom error correction in speaking differ according to students' level of proficiency in the language.

No significant differences were observed among the three groups of the students. Therefore, hypothesis 2 was not supported.

Regarding teacher correction of oral errors, the researcher hypothesized that Elementary students had less desire to be corrected than Intermediate and Advanced students. Some researchers and theorists claim that learners' errors should not be corrected when they are in the early stage of acquisition. VanPatten (1988) claims that when beginning language learners try to produce spontaneous speech, they are preoccupied with attending to all aspects of the language simultaneously. Therefore, average beginning learners have difficulty attending to errors and error correction. For this reason, Elementary students may not benefit a great deal from error correction, and consequently may have less desire to be corrected than Intermediate and Advanced students. However, the result does not support this.

Concerning overcorrection of errors, the researcher hypothesized that the students in Elementary level had more negative attitudes than those in Intermediate and Advanced acquisition levels. Since most 
learners in the early stage of acquisition speak relatively erroneous English, correcting all of their errors may destroy their confidence. This, in turn, may affect their desire to continue to speak English. Thus, beginning students may more strongly disagree with overcorrection than those in higher levels. However, the result of this study does not support this hypothesis.

In regard to selective error correction, the researcher hypothesized that Intermediate and Advanced students had more negative attitudes than Elementary students. The assumption was that Elementary students may appreciate selective error correction to some extent because it prevents them from losing confidence. In contrast, Intermediate and Advanced students may have a strong desire to eliminate their errors. Therefore, they may consider that selective error correction does not cater to their demands. However, the results indicated that the students showed a slight tendency toward agreement with selective error correction regardless of their proficiency level. This could be explained by the following comments provided by some students: "Erroneous English is all right if it does not interfere with the meaning of the communication," "Only errors that block communication should be corrected because the purpose of communication is to convey the meaning," "I would be discouraged to speak English if all my errors are corrected," and "Selective error correction is preferable in large classes."

Regarding peer correction, the researcher hypothesized that Advanced students had more negative attitudes than Intermediate and Elementary students. Based on the researcher's experience as a Japanese 
learner of English, she hypothesized that learners in advanced proficiency level are more sensitive about losing "face." Japanese society place emphasis on hierarchy. Reischauer (1977) explains as follows:

Japanese consider differing ranks and status natural and inevitable. In fact, their interpersonal relations and the groups into which they divide are usually structured on the assumption that there will be hierarchical differences (p.157).

Hierarchical differences include differences in educational performance. The students with superior academic achievement are highly regarded by the society, which makes them proud of themselves. In Japanese universities, the majority of the students are in intermediate and elementary levels of English proficiency (Table I, p. 44). Within each class, there exists great variability among the students' English proficiency levels. Thus, higher level proficiency students study with lower proficiency students. The researcher postulated that in terms of hierarchy, students who were "superior" in English proficiency, would not appreciate being corrected by those that were "inferior." Thus, the Advanced students might regard peer correction as "face-threatening." A few students did comment that they did not want to be corrected by peers whose English speaking proficiency was lower than theirs. However, the hypothesis that Advanced students have more negative attitudes toward peer correction than Intermediate and Elementary students was not supported.

Research Question 3: What are the general preferences for classroom error correction on different aspects of the language 
(e.g., pronunciation and grammar) among university students in Japan?

Hypothesis 3: The students prefer to have their grammatical errors corrected more than the errors of the other aspects of the language.

The respondents had a positive attitude toward the correction of errors on all five aspects of the language: grammar, phonology, vocabulary, pragmatics, and discourse. Errors relating to pragmatics received the strongest preference. Therefore, hypothesis 3 was not supported.

Regarding errors in pragmatics, the majority $(89.9 \%)$ wanted to have their oral errors corrected. Interestingly, $62 \%$ wanted that correction always. Pragmatic errors were discussed in detail in Chapter III; therefore will not be reiterated again here. The researcher, in translating the questionnaire, determined that "pragmatics" would best be interpreted into Japanese as: inappropriate expressions (e.g., When offering a drink, "Would you like some coffee"? is more appropriate than "Do you want to drink coffee"? ). The strong positive attitude toward correction of this type of error might be explained by the Japanese English education system. Through junior and senior high school students are taught English through grammar-oriented instruction. The end product of this instruction is graduates who have good knowledge of English grammar and a wide range of vocabulary. However, most of them cannot apply this knowledge to hold even a basic English conversation (Sturman, 1992). They may produce grammatically correct sentences, but may not be sure whether or not their utterances are appropriate in a specific context. This may help to explain why the students in this study showed great interest in 
correction of their inappropriate speech - "pragmatics."

In regard to phonological errors, the students $(84.7 \%)$ had a strong positive attitude. Japanese phonology does not share the same features as English phonology (Vance, 1987). Therefore, the acquisition of English pronunciation, accent, and intonation patterns is difficult for many Japanese learners of English. In addition, English is usually taught by Japanese teachers in junior and senior high school. Consequently, the students lack exposure to English from native speakers. The students' high interest in correction of phonological errors is very predictable as the researcher remembers when she was an EFL learner in Japan.

Regarding vocabulary errors, the students (77.3\%) showed a positive attitude. The students' high interest in correction of vocabulary errors could be explained by the English education that they received in junior and senior high schools. In Japan, much of the training in high school is dedicated to preparing students to pass university entrance examinations. The English language is not an exception (Reischauer, 1977). According to the researcher's knowledge as a Japanese native speaker, test-takers are expected to have a wide range of vocabulary that is covered in entrance examinations. The English instruction in junior and senior high school, which is the Grammar Translation method, emphasizes the mastery of complex grammar and the increase of vocabulary. The students simply memorize words and phrases instead of learning them in meaningful contexts. Therefore, they may not be confident about their use of appropriate words and phrases in a real-life setting. Therefore, it is not surprising that the students in this study showed high interest in 
correction of vocabulary errors.

Concerning grammatical errors, the students showed less preference for this correction than they did for pragmatics, phonology, and vocabulary. Approximately half of the students (52.2\%) showed positive attitudes toward correction of grammatical errors. The type of English instruction in Japan that the students had received could explain the reason that the students expressed less interest in this type of error. In junior and senior high school the students study complex grammatical rules that will be tested in their university entrance exams. These exams concern primarily written English. The students generally know grammatical rules very well. Thus, some of the students' grammatical errors in speaking English could be what Corder (1967) calls "mistake," i.e., errors of performance or slips rather than errors due to lack of knowledge about the grammatical rules. Thus, the students may not want to have this type of error corrected.

In regard to errors in discourse, the students showed less preference for this correction than they did for pragmatics, phonology, and vocabulary. Discourse errors were discussed in detail in Chapter III; therefore will not be reiterated again here. The researcher, in translating the questionnaire, determined that "discourse" would best be interpreted into Japanese as: organization of discourse (e.g., how to negotiate or persuade). Half of them (50.3\%) showed a positive attitude toward correction of discourse errors. The majority of the students $(86 \%)$ reported that they did not have opportunities to speak English outside of class. Therefore, correction of errors in discourse might have appeared less critical to these students' needs and experiences. 
Research Question 4: Do the general preferences for classroom error correction on different aspects of the language differ according to students' level of proficiency in the language?

Hypothesis 4: The preferences for classroom error correction on different aspects of the language differ according to students' level of proficiency in the language.

A significant difference among the three proficiency levels was observed in preference for correction of errors in discourse alone. The results indicated that the higher the proficiency level, then the more correction the students desired. The median was 3 for Elementary students, and 4 for Intermediate and Advanced students. The proportion of the Advanced students who scored 5 was larger than the proportion of the Elementary and Intermediate students. Considering the advanced skills that are required for discourse, the results appeared to be very predictable. For the students in lower proficiency levels, discourse, such as negotiation or persuasion, may appear to be beyond their abilities. Therefore, correction of errors in discourse may be less relevant to their needs.

Research Question 5: What are the general preferences for particular types of classroom error correction in speaking among university students in Japan?

Hypothesis 5: The students most prefer a correction in which the teacher presents the correct response or part of the response, and least favor a treatment in which the teacher ignores errors.

The respondents preferred four methods of correction of 
grammatical and phonological errors (See Table VI, p. 62):

1) The teacher gives the student a "hint" which might enable the student notice the error and self-correct.

2) The teacher explains why the response is incorrect.

3) The teacher points out the error, and provides the correct response.

4) The teacher presents the correct response or part of the response. The respondents did not prefer two methods of correction of grammatical and phonological errors (See Table XIII, p. 65):

1) The teacher ignores the student's errors.

2) The teacher repeats the original question asked of the student.

Hypothesis 5 was not supported in that the students most prefer a correction in which the teacher presents the correct response or part of the response. However, the hypothesized method was included in the four preferred methods.

The most preferred correction method was a technique in which the teacher gives the student a "hint" which might enable the student notice the error and self-correct. An example for correction of grammatical errors was "Where did you say you went yesterday"? An example for phonological errors was "What color of roses do you like"? This method for correcting grammatical errors was preferred by $70.0 \%$ of the respondents, and for phonological errors $64.4 \%$. This indirect correction method is intended to indicate that the student has made an error without embarrassing the student, allowing the student to save "face." In large English classes of Japanese universities, the students might feel most 
comfortable with this method of error correction.

Another preferred method was a technique in which the teacher explains why the response is incorrect. An example for correction of grammatical errors was "Go is the present tense. You need the past tense here." An example for phonological errors was (Using a picture of a mouth) "When you pronounce $\underline{\underline{r}}$ for roses, your tongue should not touch the roof of the mouth. It should..." This method for correcting grammatical errors was preferred by $64.2 \%$, and for phonological errors $62.9 \%$. This method also attempts to elicit self-correction. In addition, the questionnaire included four other correction methods which attempt to elicit self-correction. Some researchers recommend various methods which attempt to elicit self-correction (Holley \& King, 1971; Fanselow, 1977; Horner, 1988). However, the results of this study showed that the students had neither positive nor negative preference for some self-correction methods (See Table VII, p. 64). These methods simply attempt to indicate that an error has been committed, and do not provide the student with either "hints" or grammatical explanations that could lead to selfcorrection. These results suggest that students in this study may have wanted hints or explanations to help them self-correct errors successfully.

One other preferred method of error correction was a technique in which the teacher points out the error, and provides the correct response. In addition, one last preferred method was a technique in which the teacher presents the correct response or part of the response. These two methods were frequently employed by the teachers in studies which investigated actual methods of oral error correction utilized (Cathcart \& 
Olsen, 1976; Fanselow, 1977; Nystrom, 1983). Hammerly (1991) opposes this type of correction because it does not treat the cause of errors. He claims that "correction must reorganize their cognitive structures, filling in gaps or replacing their [the students'] incorrect mental rules with accurate ones" (p.93). However, the majority of the students in this study showed preference for this error correction method.

The least preferred method was a technique in which the teacher ignores the student's errors. The majority $(88.8 \%)$ did not prefer this method. This result supported hypothesis 5 that university students of English in Japan least favor a treatment in which the teacher ignores their errors. This result is consistent with the finding that the majority of the students showed a strong positive attitude toward teacher correction of their oral errors. The students in the studies of Cathcart and Olsen (1976) and Oladejo (1993) also did not prefer this method. Despite its unpopularity among the learners, ignoring the students' errors is one of the treatments often employed by the ESL teachers (Fanselow, 1977).

Research Question 6: Do the the general preferences for particular types of classroom error correction in speaking differ according to students' level of proficiency in the language?

Hypothesis 6: The preferences for particular types of classroom error correction differ according to students' level of proficiency in the language.

A significant difference among the three proficiency levels was observed in preference for one correction method for grammatical and phonological errors. The method was the one in which the teacher 
presents the correct response or part of the response. Intermediate and Advanced students preferred this method more than Elementary students. The researcher is unclear why the students' preferences were in this manner.

\section{DISCUSSION OF DIFFERENCES IN PREFERENCE BETWEEN SUBGROUPS}

It is interesting to note that few differences in preference were observed between subgroups.

\section{Differences Between Gender}

Concerning differences between gender groups, preference for the correction method in which the teacher ignores the student's errors was the only area which showed a significant difference. Although the students' overall attitudes toward this method were strongly negative, some male students regarded this method as "very good" $(=5)$. None of the female students rated it higher than 4. This may indicate that some male students strongly desired not to be corrected by their teachers in front of peers. These students may be very sensitive about keeping/losing "face."

\section{Differences Among Academic Major Fields}

The differences among major fields were observed in their preferences for overcorrection of errors, correction of phonological errors and errors in discourse. The median scores of the English Majors were higher than those of Non-English Majors. 
Regarding overcorrection, the median of English Majors was 3, and 2 for Non-English Majors. This indicates that Non-English Major students had negative attitudes toward overcorrection of errors, while English Major students had neither positive nor negative attitudes. This might relate to the oral proficiency levels of Non-English Majors. The researcher postulates that Non-English Major students may have lower oral proficiency levels with many oral errors. Thus they may have negative attitudes toward overcorrection of errors because if the teacher corrects all the errors they make, they would quickly become discouraged.

Concerning phonological errors, the median of English Majors was 5, and 4 for Non-English Majors. Considering the needs and interests in English among English Major students, this result is predictable.

In regard to discourse, the median of English Majors was 4, and 3 for Non-English Majors. Again, this result is predictable, considering the needs and interests in English among English Major students.

\section{Differences Between Other Subgroups}

Except in preference for correction of errors in discourse, there were no significant differences in preference between: 1) the students who wanted to improve English and those who did not, 2) the students who had lived in an English-speaking country for one month or more and those who had lived less than one month or not at all, and 3) the students who had opportunities to speak English outside of class and those who did not have opportunities. The results do not support the researcher's assumption that the experience of interaction with native speakers might 
influence the preference for error correction among English learners.

Positive attitudes toward correction of errors in discourse were observed among: 1) the students who wanted to improve English, 2) those who lived in an English-speaking country for one month or more, and 3) those who had opportunities to speak English outside of class. On the other hand, the rest of the students neither preferred nor disliked correction of discourse errors. Since the students who lived in an Englishspeaking country for one month of more could have spoken English at the discourse level with native speakers, it is not surprising that they indicated positive attitudes toward correction of discourse errors. It is also predictable that the students who had opportunities to speak English outside of classroom had positive attitudes toward correction of discourse errors, considering their amount of exposure to English of native speakers.

\section{LIMITATIONS}

It is important to recognize limitations of a research study in order to determine its reliability and validity. The following limitations are noted by the researcher.

1. The first limitation is that the sample of this study was not a true random sample, but a 'convenient' sample. However, the sample of this study provided a varied population mix, which increased the degree of representativeness of the target population.

2. A second limitation is the use of self-report data. This limitation is described by Babbie (1995). "Survey research has the weakness of being 
somewhat artificial and potentially superficial" (p.277). It is a major concern for researchers whether or not a survey adequately measures the beliefs or attitudes of the people. However, the confidentiality of a selfreport is greater than that of an interview. In addition, the sample size using self-report is greatly increased due to time and convenience factors as opposed to interviews which are a time-consuming process.

3. A third limitation might be the length and the depth of the questions. The questionnaire contained 45 question items. The completion of the questionnaire was determined to take approximately 15 minutes based on the results of the pretests. However, the researcher observed some students completed the questionnaire quickly, and others took their time. She also noticed that some others did not appear to have enough time to answer the questions in the last section. Therefore, the results of the questionnaire were dependent upon how serious the respondents were. However, the length of the questionnaire allowed for extensive demographic information, specific information regarding preference in error correction, and comparison among proficiency groups.

4. A further limitation concerns self-rating employed in this study as the method for determining respondents' level of proficiency. The students rated their oral English abilities (See Appendix A). According to one of the teachers who distributed the questionnaire, some of his students appeared to overestimate their abilities. This problem was not indicated from the results of the pilot studies, which dealt with Japanese undergraduate students at Portland State University. Even with this possible limitation, the self-rating was an important part of the study as it 
allowed the grouping of students by proficiency levels. This grouping would have been difficult if dependent upon the teachers because of the large number of students in their classes.

5. The fifth limitation refers to the administration procedures of the questionnaire. Approximately two fifths of the questionnaires was administered by the teachers of the subjects. Three fifths of them was administered by the researcher. Although the researcher gave the teachers the instructions to administer the questionnaire, she was not able to ensure that they followed the instructions completely (e.g., amount of time allowed). However, due to time constraints and the larger sample desired, the researcher was not able to personally attend each class.

\section{IMPLICATIONS}

In Japanese universities, English classes are usually large. Thus, it is impractical to spend much of the instruction time dealing with students' errors. The teachers often require the students to engage in communicative tasks in pairs and groups (O'Sullivan, 1996). Inevitably, the teachers cannot observe all the errors made by the students. Even if the teachers notice errors, they may consider interrupting the students by correcting their errors as inappropriate.

One obvious implication of the findings of the study is that certain differences appear to exist between the students' expectations and the teachers' pedagogical practice. Some researchers believe that matching the expectations of teachers and learners contributes to successful language 
learning (Horwitz, 1990; McCarger, 1993). However, it may be inappropriate to infer from this study that EFL teachers in Japan should or should not correct the errors of their students. A decision whether or not correct their students' errors, which errors to correct, when to correct, and how to correct should be entrusted to the teachers, who know individual students' personality, motivation, preference, interest and such.

When the situation does not allow the teachers to alter their pedagogical practice, they can explain the reason to their students. Expectational conflict between the teachers and the students could be at least minimized by such an explanation.

\section{SUGGESTIONS FOR FURTHER STUDY}

The researcher was pleased with the cooperation of the teachers and their desire to know their students' preferences. The teachers' interest in discovering their students' preferences and foregoing limitations suggest future research.

In light of the results from this study, the researcher recommends future research on the preference for error correction among university students of English in Japan. One recommendation is for further research on preference for correction methods. For error correction to be effective, how correction methods are actually practiced is a crucial concern. The examples of the correction methods listed in the questionnaire are sometimes used in combinations. Therefore, it would be meaningful to investigate the preference of the students regarding corrections which 
include more than one method.

Additional research could address the reasons for the students' preferences for particular correction methods. The results would be of benefit to both teachers and students because they may provide the research with "useful/insightful" qualitative data (Nunan, 1993, p.145). 


\section{REFERENCES}

Allwright, R. L. (1975). Problems in the study of the language teacher's treatment of learner error. In M. K. Burt, \& H. C. Dulay, (Eds.) On TESOL'75: New Directions in second language learning, teaching and bilingual education (pp.96-109). Washington, D.C.: TESOL

Allwright, R. L. (1991). Focus on the language classroom: An introduction to classroom research for language teachers. Cambridge: Cambridge University Press.

Asher, J. (1982). Learning another language through actions: The complete teachers' guidebook. Los Gatos, CA: Sky Oaks Production.

Babbie, E. (1995). The practice of social research. Belmont, CA: Wadsworth Publishing Company.

Bailey, N., Madden, C., \& Krashen S. D. (1974). Is there a "natural sequence" in adult second language learning? Language Learning, 24 (2), 235243.

Brooks, N. (1960). Language and language learning. (2nd Ed.). New York: Harcourt, Brace and World, Inc. cited in Hendrickson, 1978.

Brown, H. D. (1993). Principles of language learning and teaching. (3rd Ed.). Englewood Cliffs, NJ: Prentice Hall Regents.

Brumfit, C. J. (1980). From defining to designing: Communicative specifications versus communicative methodology in foreign language teaching. Studies in Second Language Acquisition, $\underline{3}, 1-16$.

Bruton, A. \& Samuda, V. (1980). Learner and teacher roles in the treatment of oral error in group work. RELC Journal, 11 (2), 49-63.

Burt, M. K. (1975). Error analysis in the adult EFL classroom. TESOL Quarterly $9(1), 53-63$.

Burt, M. K. \& Kiparsky, C. (1974). Global and local mistakes. In J. H. Schuman and N. Stenson (Eds.). New frontiers in second language learning (pp.71-80). Rowley, Mass: Newbury House. 
Byrnes, H. \& Thompson, I. (1989). The ACTFL Oral Proficiency Interview: Tester training manual. ACTFL Inc.: New York.

Carroll, S., \& Swain, M. (1992). The role of feedback in adult second language acquisition: Error correction and morphological generalization. Applied Psycholinguistics, 13, 173-198.

Carroll, S., \& Swain, M. (1993). Explicit and implicit negative feedback: An empirical study of the learning of linguistic generalizations. Studies in Second Language Acquisition, 15, 357-386.

Cathcart, R.L., \& Olsen, J. W. B. (1976). Teachers' and students' preference for correction of classroom conversation errors. In J. F. Fanselow \& R. H. Crymes (Eds.) On TESOL '76 (pp.41-53). Washington, D.C.: TESOL.

Chaudron, C. (1977). A descriptive model of discourse in the corrective treatment of learners' errors. Language Learning, 27, 29-46.

Chaudron, C. (1986). Teachers' priorities in correcting learners' errors in French immersion classes. In R. R. Day (Ed.), Talking to learn: Conversation in second language acquisition (pp. 64-84). Rowley, Mass: Newbury House.

Chenoweth, N.A., Day, R.R., Chun, A.E., \& Luppescu, S. (1983). Attitudes and preferences of ESL students to error correction, Studies in Second Language Acquisition, 6(1), 79-87.

Chomsky, N. (1975). Reflections on language. New York: Pantheon Books.

Christison, M. A., \& Krahnke, K. J. (1986). Students' perceptions of academic language study. TESOL Quarterly, 20, 61-81.

Chun. A. E. , Day, R. R., Chenoweth, N. A., \& Luppescu, S. (1982). Errors , interaction, and correction: A study on native-nonnative conversations. TESOL Quarterly, 16 (4), 537-547.

Cohen, A. D. (1975). Error correction and the training of language teachers. Modern Language Journal, $\underline{59}$, 414-422.

Cole, M. (1989). A cross-cultural inquiry into the meaning of face in the Iapanese and United States cultures. Paper presented at the Speech Communication Association convention, San Fransisco. cited in Gudykunst, W. B. \& Nishida, T. (1993). 
Corder, S. P. (1967). The significance of learner's errors. International Review of Applied Linguistics, $\underline{5}, 161-170$.

Corder, S. P. (1975). The language of second language learners: The broader issues. Modern Language Journal, 59, 409-413.

Corder, S. P. (1983). A role for the mother tongue. In S. Gass \& L. Selinker (Eds.) Language Transfer in language learning (pp. 85-97). Rowley, MA: Newbury House.

Day, R. R. , Chenoweth, N. A., Chun, A. E. , \& Luppescu, S. (1984). Corrective feedback in native-nonnative discourse. Language Learning, 34 (2), 19-45.

Dekeyser, R. M. (1993). The effect of error correction on L2 grammar knowledge and oral proficiency. Modern Language Journal, 77, 501514.

Dulay, H. C. \& Burt M. K. (1974). Natural sequences in child second language acquisition. Language Learning, 24 (1), 37-53.

Dulay, H. C. \& Burt, M. K. (1977). Remarks on creativity in language acquisition. In M. K. Burt. H. Dulay, \& M. Finocchiaro (Eds.). Viewpoints on English as a second language. New York: Regents. cited in Krashen (1982)

Eskey, D. E. (1983). Meanwhile back in the real world...: Accuracy and fluency in second language teaching. TESOL Quarterly, 17, 315-323.

Fanselow, J. F. (1977). The treatment of error in oral work. Foreign Language Annals, 10 (5), 583-593.

Foss, K. A., \& Reitzel, A. C. (1988). A relational model for managing second language anxiety. TESOL Quarterly, 22(3), 437-454.

Gainer, G. T. (1989). Clozing in on oral errors. ELT Journal, $\underline{43}$ (2), 45-49.

Gorbet, F. (1974). Error analysis: What the teacher can do: A new perspective. Ottawa: Research Division, Public Service Commission of Canada. (EDRS: ED 100193). 
Gudykunst, W. B. \& Nishida, T. (1993). Interpersonal and intergroup communication in Japan and the United States. In W. B. (Ed.). Communication in Japan and the United States. (pp.149-214). Albany, NW: State University of New York Press.

Hamayan, E. V. \& Tucker, G. R. (1980). Language input in the bilingual classroom and its relationship to second language achievement. TESOL Quarterly, 14, 453-468.

Hammerly, H. (1987). The immersion approach: Litmus test of second language acquisition through classroom communication. Modern Language Journal, 71, 395-401.

Hammerly, H. (1991). Fluency and accuracy. Bistol, PA: Multilingual Matters.

Hanzeli, V. E. (1975). Learner's language: Implications of recent research for foreign language instruction. The Modern Language Journal, $\underline{59}$, 426432.

Hendrickson, J. M. (1976). Error analysis and selective correction in the adult ESL classroom: An experiment. ERIC: Center for Applied Linguistics, Arlington, Virginia. (EDRS: ED 135260).

Hendrickson, J. M. (1978). Error correction in foreign language teaching: Recent theory, research, and practice. Modern Language Journal. $\underline{62}$, 387-398.

Herron, C. (1981). The treatment of errors in oral activities: Developing instructional strategies. The French Review, $\underline{54}$ (1), 6-16.

Herron, C. (1991). The Garden Path correction strategy in the foreign language classroom. The French Review, 64(6), 966-977.

Herron, C., \& Tomasello, M. (1988). Learning grammatical structures in a foreign language: Modeling versus feedback. The French Review, 61(6), 910-927.

Higgs, T. V. \& Clifford, R. (1982). The push toward communication. In T. V. Higgs (Ed.) Curriculum, competence, and the foreign language teacher: ACTFL foreign language education series (pp.57-79). Lincolnwood, IL: National Textbook Company. 
Higgs, T. V. (1985). Teaching grammar for proficiency. Foreign Language Annals, 18, 289-296.

Holley, F. M. \& King, J. K. (1971). Imitation and correction in foreign language learning. The Modern Language Journal, 55, 494-498.

Horner, D. (1988). Classroom correction: Is it correct? System, 16 (2), 213-220.

Horwitz, E. K. (1988). The beliefs about language learning of beginning university foreign language students. The Modern Language Journal, 72, 283-294.

Horwitz, E. K. (1990). Attending to the affective domain in the foreign language classroom. In S. Magnan (Ed.) Shifting the instructional focus to the learner. (pp. 15-33). Middlebury, VT: Northeast Conference on the Teaching of Foreign Languages.

Horwitz, E. K., Horwitz, M. B., \& Cope, J. (1986). Foreign language classroom anxiety. Modern Language Journal, 70, 125-132.

Hughes, A. \& Lascaratou, C. (1982). Competing criteria for error gravity. ELT Journal, $\underline{36}, 175-182$.

Hymes, D. (1971). Competence and performance in linguistic theory. In R. Huxley \& E. Ingram (Eds.). Language acquisition: Models and methods (pp.3-28). London: Academic Press. cited in Savignon, 1983.

Imai, J. (1989). Comparative study on effectiveness of corrective/noncorrective techniques in EFL classes at college level in Japan. Unpublished master's thesis, Portland State University, Portland, OR.

Johnson, K. (1981). Mistake correction. ELT Journal, 42 (2), 89-96.

Kasper, G. (1985). Repair in foreign language teaching. Studies in Second Language Acquisition, $\mathbf{7}$, 200-215.

$\mathrm{Ke}, \mathrm{C}$. (1992). Challenges to the proficiency movement: The issue of accuracy. Oregon: University of Oregon. (ERIC Document Reproduction Service ED 353816).

Kern, R. G. (1995). Students' and teachers' beliefs about language learning. Foreign Language Annals, 28, 71-92. 
Krashen, S. (1981). The monitor model for second language acquisition. In R. C. Gingras, (Ed.), Second language acquisition and foreign language teaching (pp.1-26). Washington, D.C.: Center for Applied Linguistics.

Krashen, S. D. (1982). Principles and practice in second language acquisition. Oxford: Pergamon.

Krashen, S. D. (1985a). The Input Hypothesis: issues and implications. New York: Longman.

Krashen, S. D. (1985b). Inquiries \& Insights: Second language teaching immersion \& bilingual education literacy. Hayward, CA: Janus Book Publishers, Ins.

/Krashen, S. \& Seliger, H. (1975). The essential contributions of formal instruction in adult second language learning. TESOL Quarterly, $\underline{9}$, 173-183.

Krashen, S. \& Terrell, T. (1983). The natural approach. New York: Pergamon.

Larsen-Freeman, D. (1979). Issues in the teaching of grammar. In M. CelceMurcia \& L. McIntosh (Eds.), Teaching English as a second or foreign language (pp. 217-228). Rowley, MA: Newbury House.

Larsen-Freeman, D. \& Long, M. H. (1994). An introduction to second language acquisition research. New York: Longman.

Lennon, P. (1991). Error: Some problems of definition, identification, and distinction. Applied Linguistics, 12(2), 180-195.

Lightbown, P. M.,\& Spada, N. (1990). Focus-on-form and corrective feedback in communicative language teaching. Studies in Second Language Acquisition, 12, 429-448.

Little, G. D. \& Sanders, S. L. (1990). Resistance to learning?: Student reaction to communicative language teaching. South Carolina: University of South Carolina. (ERIC Document Reproduction Service ED 319232).

Long, M. (1977). Teacher feedback on learner error: Mapping cognitions. In H. D. Brown, C. A. Yorio, \& R. H. Crymes (Eds.). On TESOL '77: Teaching and learning English as a second language: Trends in research and practice, (pp. 278-294). Washington D. C.: TESOL. 
Long, M. (1983). Does second language instruction make a difference? A review of research. TESOL Quarterly, 17(3), 359-382.

Major, R. C. (1988). Balancing form and function. International Review of Applied Linguistics, 26, 81-100.

Mayer, R. (1985). A use of the Natural Approach in a beginning level English as a foreign language class in Barcelona, Spain. (ERIC Document Reproduction Service No. ED306769).

Mazur, G. S. (1986). Communicative competence in the beginning foreign language class: Problems and suggestions. Washington: Washington State University. (ERIC Document Reproduction Service ED 285388)

McCargar. D. F. (1993). Teacher and student role expectations: Cross-cultural differences and implications, The Modern Language Journal, 77 (2), 192-207.

Meisel, J. M., Clahsen, H., \& Pienemann, M. (1981). On determining developmental stages in natural second language acquisition. Studies in Second Language Acquisition, $6,186-214$.

Mey, J. L. (1993). Pragmatic: An introduction. Cambridge, MA: Blackwell Publishers.

Mings, R. C. (1993). Changing Perspectives on the utility of error correction in second language acquisition. Foreign Language Annals, 26 (2), 171179 .

Montgomery, C. \& Eisenstein, M. (1985). Real reality revisited: an experimental communicative course in ESL. TESOL Quarterly, 19(2), 317-334.

Moskowitz, G. (1976). The classroom interaction of outstanding foreign language teachers. Foreign Language Annals, 9 (2), 135-157.

Mukattash, L. (1986). Persistence of fossilization. International Review of Applied Linguistics, 24, 187-203.

Nakanish, M. (1986). Perception of self-disclosure in initial interaction: A Japanese sample. Human Communication Research, 13, 167-190.

Nunan, D. (1993). Research methods in language learning. New York: Cambridge University Press. 
Nystrom, N. J. (1983). Teacher-student interaction in bilingual classrooms: Four approaches to error feedback. In H. W. Seliger \& M. H. Long (Eds.) Classroom oriented research in second language acquisition (pp. 169-188). Rowely, MA: Newbury House.

Oladejo, J. A. (1993). Error correction in ESL: Learners' preference. TESL Canada Journal, 10, 71-89.

Oller, J. W., Jr. (1981). Research on the measurement of affective variables: Some remaining questions. In Roger W. Andersen (Ed.). New dimensions in second language acquisition research (pp.14-27). Rowley, MA: Newbury House Publishers.

Omaggio, A. (1983). Methodology in transition: The new focus on proficiency. The Modern Language Journal, 67(4), 330-331.

O'Sullivan, J. (1996). Teaching English in Japan. Lincolnwood, IL: Passport Books.

Parkin, M. (1981). The relevance of interlanguage and pidginization to French immersion schooling. Ontario: Ottawa Board of Education. (ERIC Document Production Service No. ED 230033).

Pienemann, M., Johnson, M., \& Brindley, G. (1988). Constructing an acquisition based procedure for second language assessment. Studies in Second Language Acquisition, 10, 217-243.

Powell, P. B. (1975). Moi Tarzan, Vous Jane?: A study of communicative competence. Foreign Language Annals, $\underline{8}$, 38-42.

Purcell, E., \& Suter, R. (1980). Predictors of pronunciation accuracy: A reexamination. Language Learning, $\underline{30}(2), 271-287$.

Ramirez, A. \& Stromquist, N. (1979). ESL methodology and student language learning in bilingual elementary schools. TESOL Quarterly, $\underline{13}, 145-158$.

Reed. D. J. (1992). The relationship between criterion-based levels of oral proficiency and norm-referenced scores of general proficiency in English as a second language. System, 20 (3), 329-345.

Reischauer, E. O. (1977). The Japanese. Cambridge, MA: The Belknap Press of Harvard University Press. 
Richards, J. C. (1985). The context of language teaching. Cambridge: Cambridge University Press.

Riley, P. (1989). "Well don't blame me" On the interpretation of pragmatic errors. In W. Oleksy (Ed.). Contrastive pragmatics. (pp.231-250). Philadelphia: John Benjamins Publishing Company.

Rivers, W. M. (1986). Comprehension and production in interactive language teaching. Modern Language Journal, $\underline{70}$, 1-7.

Ross, D. (1981). From theory to practice: Some critical comments on the communicative approach to language teaching. Language Learning, 31(1), 223-242.

Savignon, S. (1982). Three Americans in Paris: A look at 'natural' second language acquisition. Modern Language Journal, 65, 241-247.

Savignon, S. (1983). Communicative competence: theory and classroom practice. Reading, MA: Addison-Wesley Publishing Company.

Scarcella R. (1992). Interethnic conversation and second language acquisition: Discourse accent revisited. In S. M. Gass \& L. Selinker (Eds.). Language transfer in language learning (pp.109-137). Philadelphia: John Benjamins Publishing Company.

Schachter, J. (1981). The hand signal system. TESOL Quartery, 15 (2), 125138.

Schmidt, T. W. \& Frota, N. G. (1986). Developing basic conversational ability in a second language: a case study of an adult learner of Portuguese. In R, R. Day. (Ed.). Talking to learn: conversation in second language acquisition (pp. 237-326). Rowley, MA: Newbury House.

Seliger, H. W. (1983). Learner interaction in classroom and its effect on language acquisition. In H. W. Seliger \& M. H. Long (Eds.) Classroom-oriented research in second language acquisition (pp. 246266). Rowley, MA: Newbury House.

Selinker, L. (1972). Interlanguage. International Review of Applied Linguistics, 10, 209-213. 
Sharwood Smith, M. (1991). Speaking to many minds: On the relevance of different types of language information for the L2 learner. Second Language Research, $\underline{7}$ (2), 118-132.

Sternglass, M. S. (1974). Close similarities in dialect features of black and white college students in remedial composition classes. TESOL Quarterly, $\underline{8}, 271-283$.

Strevens, P. (1977). Causes of failure and conditions for success in the learning and teaching of foreign languages. On TESOL'77 (pp.273277).Washington, D.C.: TESOL.

Sturman, P. (1992). Team teaching: a case study from Japan. In D. Nunan. (Ed.). Collaborative language learning and teaching. (pp. 141-161). Cambridge: Cambridge University Press.

Terrell, T. D. (1977). A natural approach to second language acquisition and learning. The Modern Language Journal, 61, 325-337.

Terrell, T. D. (1986). Acquisition in the Natural Approach: The binding/access framework. The Modern Language Journal, 70, 213227.

You, L. (1991). How students perceive their teachers' error corrections. Paper presented at the ACTFL Annual Meeting, Washington, DC., November 23, 1991. sited in Ke (1992).

Valette, R. M. (1991). Proficiency and the prevention of fossilization-an editorial. The Modern Language Journal, 75, 325-328.

Vance, T., J. (1987). An introduction to Japanese phonology. New York: State University of New York Press.

VanPatten, B. (1988). How juries get hung: Problems with the evidence for a focus on form in teaching. Language Learning, $\underline{38}, 243-260$.

Vigil, N.A. \& Oller, J.W. (1976). Rule fossilization: A tentative model. Language Learning, 26, 281-295.

Walker, J. L. (1973). Opinions of university students about language teaching. Foreign Language Annals, $\underline{7}, 102-105$. 
Widdowson, H. G. (1989). Knowledge of language and ability for use.

Applied Linguistics, 10 (2), 128-137.

Woods, D. (1989). Error correction and the improvement of language form. TESL Canada Journal, 6 (2), 60-72.

Zamel, V. (1981). Cybernetics: A model for feedback in the ESL classroom. TESOL Quarterly, 15, 139-150. 
APPENDIX A

QUESTIONNAIRE IN ENGLISH 


\section{SURVEY OF CORRECTION OF ENGLISH LEARNERS' ERRORS}

It is natural for English learners to make grammatical or pronunciation errors when speaking English. This survey will investigate general preferences for correction of such errors. The study is being performed by Akemi Katayama, a graduate student at Portland State University, as part of her master's thesis research. It is not being conducted by your university. Your answers to these questions will not affect your grade at all. All information which you give will be kept confidential, and the identity of all subjects will also be kept confidential in the study. All information provided by you will be dealt as a group data, and the results of the study may be used as a reference by your teacher(s). This is an anonymous questionnaire, and participation is voluntary. You are free to leave any answers blank, or discontinue participation in the survey at any time. If you do not want to participate in this study, please turn in a blank questionnaire to the researcher. In addition, you are free to leave class if you do not want to participate in this study. The questionnaire will take about 15 minutes to complete.

Consent: I have read and understood the above information, and agree to participate in this study.

(circle one) Yes No Date:

If you have concerns or questions about this study, please contact the following. (Please keep a blue sheet inserted in this questionnaire for your copy.)

Human Subjects Research Review Committee Chair Office of Research and Sponsored Projects 105 Neuberger Hall, Portland State University Portland, OR 97207-0751 United States of America phone: (503) 725-341 
A. Please check the appropriate answers or write an answer in the space provided.

1. University Name:

2. Major:

3. Gender:

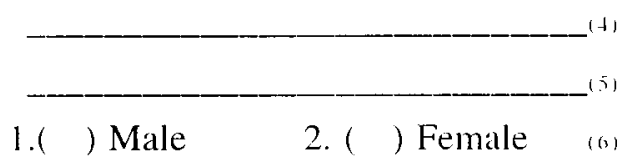

4. How long have you stayed in an English-speaking country? (Please circle 0 if you do not have any such experience)

-

5. Do you speak English outside of class? (11,

1. ( ) yes

2. ( ) no

6. Do you want to improve your speaking skills in English? (12)

1. ( ) yes

2. ( ) no

7. What do you believe you can do in English? Regardless whether or not you have actually performed, check all the appropriate answers. (Please do not over-analyze.)

a-13 () I can exchange greetings.

b-14 ( ) I can communicate with isolated words.

c-is ( ) I can communicate minimally with isolated words and memorized phrases.

d-16 ( ) I can introduce myself.

e-17 ( ) I can order food.

f-I ( ) I can ask directions.

g-Iy ( ) I can shop.

h-20 ( ) I can talk simply about myself and my family.

i-21 ( ) I can participate in simple conversation on personal history;

e.g., hometown and present job.

j-22 ( ) I can participate in simple conversation on personal weekend and leisure time activities.

$\mathrm{k}-2.3$ ( ) I can handle most uncomplicated communication and social situations with ease.

1-24 ( ) I can handle relatively complicated everyday situations.

m-2s ( ) I can handle routine school requirements.

$\mathrm{n}-20$ ( ) I can work.

$0-27$ ( ) I can explain my opinions and support them.

p-28 ( ) I can hypothesize and explain in detail.

q-29 () I can narrate past events.

$r-30$ ( ) I can debate on current events and social issues. 
B. The following questions concern correction of spoken errors. For each question, make your choice based on your learning experience up until now including in junior high and senior high school and private English conversation schools.

If you "totally disagree" to a statement, circle "I". If you "totally agree," circle "5".

$\begin{array}{lc}\text { strongly } & \text { strongly } \\ \text { disagree } & \text { agree }\end{array}$
a) I want teachers to correct my errors in speaking.
Please try to provide the reason for your choice.

b) Teachers should correct all errors that learners make in speaking English.133)

$\begin{array}{lllll}1 & 2 & 3 & 4 & 5\end{array}$

Please try to provide the reason for your choice.

c) Teachers should correct only the errors that they interfere with communication.

Please try to provide the reason for your choice.

d) I want my classmates to correct my oral errors in group work.

$\begin{array}{lllll}1 & 2 & 3 & 4 & 5\end{array}$


C. How often do you want to have your errors corrected? If you prefer "never," circle 1 . If you prefer"always," circle "5." Circle the appropriate number for each item.

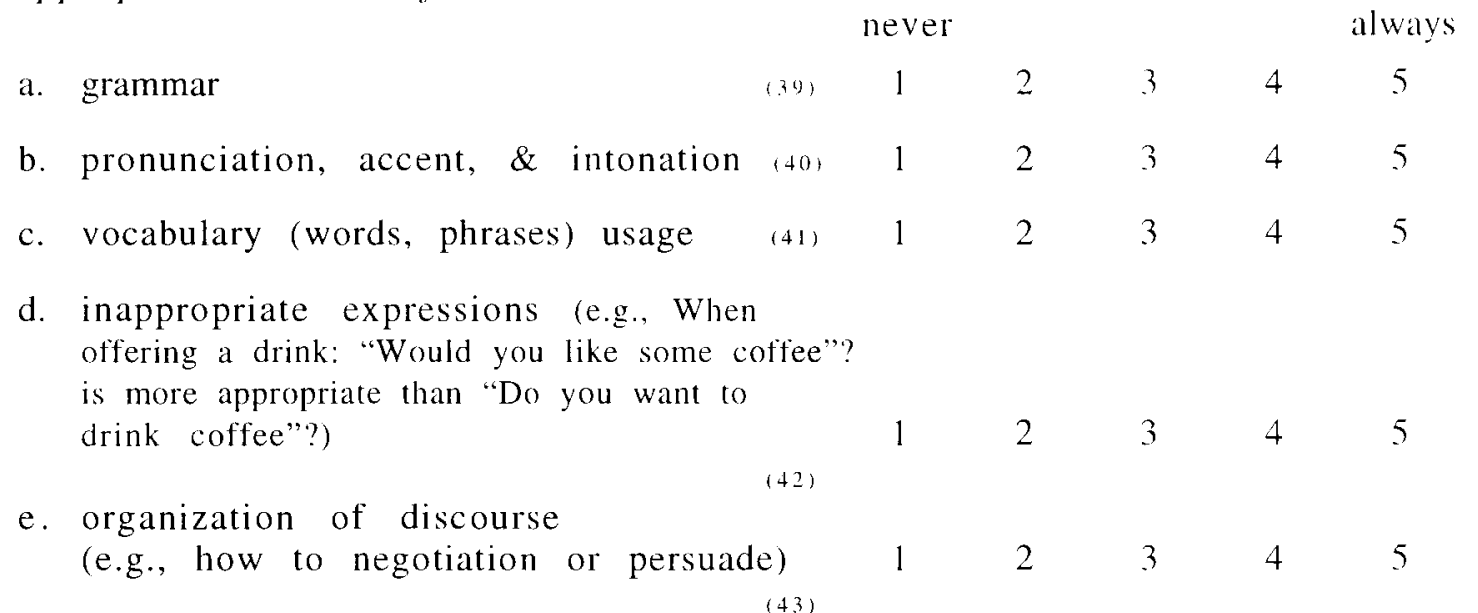

D. Teachers reaction to students' errors in speaking English are various. The following a-j are examples of correction techniques. They are sometimes used in combination. However, please rate them as individual methods here. If you think a method "not good," circle "I." If you think a method very good," circle "5."

Example of grammatical error:

Example of pronunciation error:

Teacher: "Where did you go yesterday"? T: "What kind of flowers do you like best"? Student: "I go to the park."

S: "I like loses best."

not good

very good

a) Teacher(T) ignores Student's(S) error. $\quad 1 \quad 20 \begin{array}{lllll} & 2 & 3 & 4 & 5\end{array}$

b) $\mathrm{T}$ presents the correct response or part of the response.

For grammatical error: "I went to the $\begin{array}{lllllll}\text { park." or "Went." } & \text { (45) } & 1 & 2 & 3 & 4 & 5\end{array}$

For pronunciation error:"I like roses best." or "Roses."

(46) $\quad 1 \quad 2 \quad 3 \quad 4 \quad 5$

c) $T$ points out the error, and provides the correct response.

G: "Go is wrong. You should say went." (47) 1 w

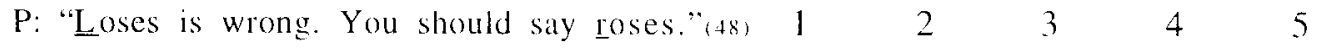


d) $\mathrm{T}$ indicates that an error occured

not good

very good

by nonverbal behavior, such as

gesture and facial expressions.

e) $\mathrm{T}$ repeats the original question.

G: "Where did you go yesterday"?

(50)

P: "What kind of flowers do you like best"? (51) 1

$\begin{array}{llll}2 & 3 & 4 & 5 \\ 2 & 3 & 4 & 5\end{array}$

f) $T$ asks $S$ to repeat the utterance.
G: "Please say that again."
2
3
4
5
P: "Please say that again."
(53)
2
34
5

g) $\mathrm{T}$ gives $\mathrm{S}$ a hint which might enable

$S$ to notice the error and self-correct.

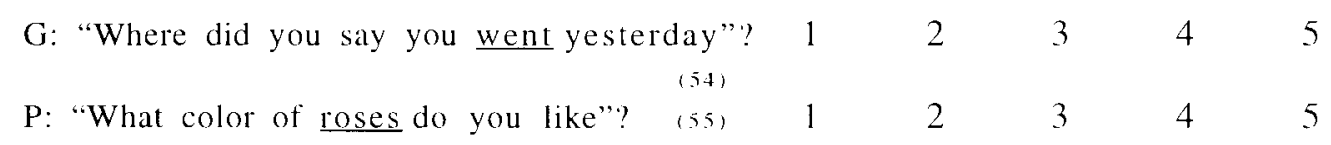

h) T repeats $S$ 's utterance up to the error, and waits for self-correction.
G: "I..."
P: "I like ..."

\begin{tabular}{|c|c|c|c|c|}
\hline (56) & 1 & 2 & 3 & 4 \\
\hline (57) & 1 & 2 & 3 & 4 \\
\hline
\end{tabular}

i) $\mathrm{T}$ indicates the error.
G: "No. Not go."
P: "No. Not loses."

\begin{tabular}{|c|c|c|c|c|}
\hline (58) & 1 & 2 & 3 & 4 \\
\hline (59) & 1 & 2 & 3 & \\
\hline
\end{tabular}

j) $\mathrm{T}$ explains why the response is incorrect.

$\mathrm{G}$ : "Go is the present tense. You need the past

tense here."

(60)

P: (Using a picture of a mouth) "When you pronounce $\underline{r}$ for roses, your tongue should not touch the roof the mouth. It should..."

Thank you very much for your participation!' 
APPENDIX B

QUESTIONNAIRE IN JAPANESE 


\section{英語学習者の「誤り」の矯正に関するアンケート}

英語学習者が英語を話す時に、文法や発音などを間違えるのは、自然な現象です。このアンケート は、その誤りに対する矯正法に関しての意識調查です。調查は、ポートランド州立大学大学院生である 片山明美が、修士論文の研究の一端として行うもので、あなたの大学が行う調查ではありません。あな たの回答は学業成績とは全く関連がありません。回答によって得られた情報は秘密厳守とすることを確 約します。この調查で得た情報は、すべてグループデータとして扱われ、結果は今後の授業の参考に される可能性むあります。このアンケートは無記名式で、自由参加です。全問回答しなくてむ、途中で やめても構いません。不参加の場合は、白紙のままアンケート用紙を提出してください。 なお、不参加の方は、先に退室なさっても構いません。アンケート記入に要する時間は 15 分位です。

同意： 上記の説明を読み、理解しました。 調查参加に同意します。

$$
\text { (どちらかを○で囲んでくだい) はいいいえ，日付： }
$$

この調査に関してご䐝問等がありましたら、下乵の方までこ連絡ください。（アンケートに挟んである ブルーの用紙は、控えとして保算してください)

Human Subject Research Review Committee Chair, Office of Research and Sponsored Projects 105 Neuberger Hall, Portland State University, Portland, OR 97207-0751

United States of America, phone: (503) 725-3417

A 下記の質問にお答えください。

1 大学名 :

2 専攻:

3 性別:

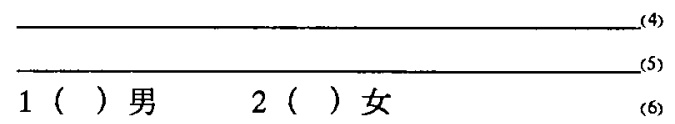

4 アメリカなど英語が日常使われている国に滞在した期間は？（経験がない場合は、0を記入） ${ }_{(78)}$ 年

5 授業中以外に、普段英語を話す機会がありますか。

(11)

1（）はい

2（）いいえ

2ページ目へ進んでください。 
6 英会話力を向上させたいと思いますか。(12)

1 ( ) はい

2( ) いいえ

7 英語でどのような事が表現できると思いますか。経験の有無を問わず、該当するものにはすべて ○をしてください。（あまり考えすぎずに回答してください）
a-1（）あいさつができる。
b-1（）単語レベルのやりとりができる。
c- 15 （）単語や丸暗記した熟語を使って、最低限の意思の疎通がはかれる。
d-16（）自己紹介ができる。
e-17（）食事の注文ができる。
f-18（）道を尋ねることができる。
g- 19 （）買い物ができる。
h-20（）自分や家族について簡単に話すことができる。
i-21（）自分の経歴（出身、現在の仕事等）に関して簡単な会話ができる。
j-22（）自分の週末や余服の過ごし方について簡単な会話ができる。
k-23（）日常生活に必要な簡単なやりとりが支障なくできる。
1-24（）日常生活に必要な多少複雑なやりとりができる。
m-25（）留学先での学校生活に必要なやりとりができる。
n-26（）仕事ができる。
0-27（）自分の意見を説明し、それを立証できる。
p-28（）何かについて詳しく説明したり、仮説を立てたりできる。
q-29（）過去の出来事について順序立てて蜕明できる。
r-30（）時事問題、社会問題についてディベート（議論）できる。 
B 以下は英語学習者の「誤り」に関する質問です。中学、高校、英会話学校なども含め、現在までの 経験に基づいてお答えください。

以下の意見に対して「全く不賛成」の場合は「1」、「大賛成」の場合は「5」を基準として 「1」から「5」のうちどれか一つに○をしてください。

a) 間连った英語を話したら、教師に直してほしい。

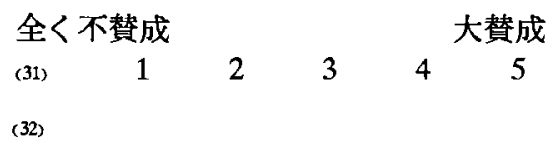
なるべく答えの理由を書いてください。

b）教師は学習者が間違って話した英語をすべて直すべきだ。(33) $\begin{array}{llllllll}1 & 2 & 3 & 4 & 5\end{array}$ なるベく答えの理由を書いてください。 (34)

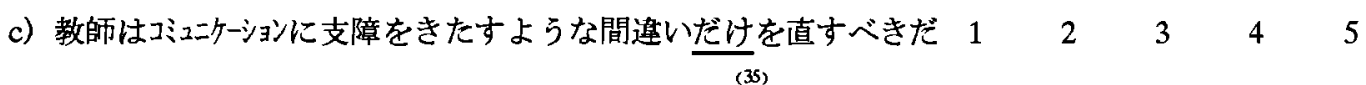
なるべく答えの理由を書いてください。 (36)

d) グループワークの時に間違った英語を話したら、

クラスメートに直してほしい。

(37) $\quad \begin{array}{lllll}1 & 2 & 3 & 4 & 5\end{array}$

なるべく答えの理由を書いてください。（38)

C 英語の「誤り」を教師に直してもらうとしたら、どの程度直してもらいたいですか。

「全然」直してもらいたくないを「1」、「いつも」直してもらいたいを「5」とし、それぞれの 項目について答えてください。

a) 文法

(39)

全然

以つむ

a)

b) 発音、アクセント、イントネーション

(40)

$\begin{array}{lllll}1 & 2 & 3 & 4 & 5\end{array}$

c)語敛（単語、熟語）の使い方

(41)

$\begin{array}{lllll}1 & 2 & 3 & 4 & 5\end{array}$

d)英語として不自然な言い回し

(例 : 人に勧める時は。

"Do you want to drink coffee?"ではなく、

"Would you like some coffee?"が自然である） (42)

e) 談話の組み立て方（例 : 交涉、説得などのし方）

$\begin{array}{lllll}1 & 2 & 3 & 4 & 5\end{array}$


D 教師は生徒が間違った英語を話した場合、いろいろな反応をします。下記のa-jはその方法例です。 複数の方法が組み合わせて使われることもありますが、ここで個別の方法として考えてください。 あなたが「良くない」と思う方法を「1」、「とてもいい」と思う方法を「5」とし、それぞれの 方法について「1」から「5」までのうちどれか一つだけに○をしてください。

\section{文法上の誤りの例}

教師 : "Where did you go yesterday?" 生徒 : "I go to the park."

a)「誤り」を無視する

\section{発音の誤りの例}

教師 : "What kind of flowers do you like best?" 生徒 : "I like loses best."

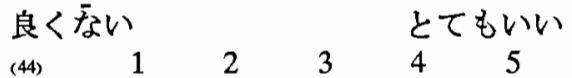

b) 正しい言い方を示す

文法の誤りに対して："I-went to the park." 又は "Went." (45) $\quad \begin{array}{lllllll} & 1 & 2 & 3 & 4 & 5\end{array}$

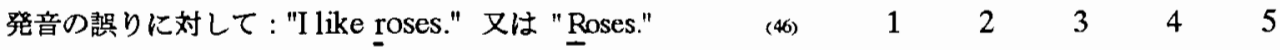

c)「誤り」を指摘し、正しい言い方を教える

文法 : "Go is wrong. You should say went."

発音 : "Loses is wrong. You should say roses." $\quad$ (48) $\quad$\begin{tabular}{lllllll}
\hline & 1 & 2 & 3 & 4 & 5
\end{tabular}

d) 動作や表情で「詩り」があったことを知らせる $\quad \begin{array}{lllllll}\text { (49) } & 1 & 2 & 3 & 4 & 5\end{array}$

e）質問をくり返す

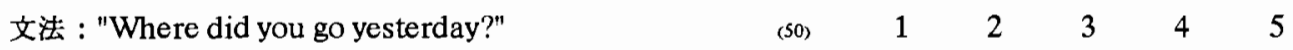

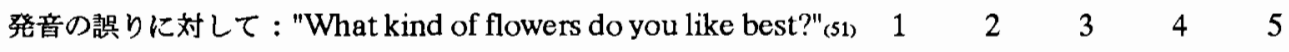

f）言い直しをさせるために、もう一度言わせる

文法："Please say that again."

発音: "Please say that again."

(52) $\quad \begin{array}{lllll}1 & 2 & 3 & 4 & 5\end{array}$

g)「誤り」に気付かせて訂正させるためにヒントを出す

文法 : "Where did you say you went yesterday?"

発音: "What color of roses do you like"?

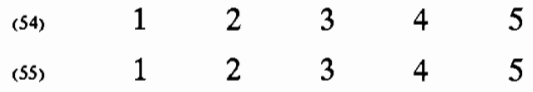

h)「誤り」の手前までくり返し、学習者が自分で訂正するのを待つ

文法 : "I ...."

発音: "I like ....:

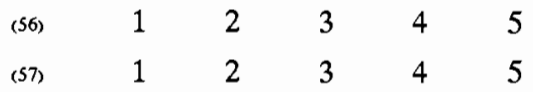

i)「誤り」を指摘する

文法 : "No. Not go."

発音 : "No. Not loses."

\begin{tabular}{|c|c|c|c|}
\hline 8) & 1 & 2 & 3 \\
\hline & 1 & 2 & 3 \\
\hline
\end{tabular}

j）「誤り」の理由を説明する

文法 : "Go is the present tense. You need the past tense here." $\quad \begin{array}{lllllll}1 & 2 & 3 & 4 & 5\end{array}$

発音 : "When you pronounce $r$ for roses, your tongue should not touch the roof of the mouth. It should..."

(61)

どうもご協力ありがとうございました。 